\title{
Malthus's Missing Women and Children: Demography and wages in historical perspective, England 1280-1850
}

\author{
Sara Horrell, Jane Humphries and Jacob Weisdorf \\ L.S.E. London, University of Oxford, Sapienza University of Rome and \\ CEPR
}

$24^{\text {th }}$ May 2020

European Economic Review, Special Issue. The Economics of Malthusianism

Editors: Timothy Swanson and Toke Aidt

\begin{abstract}
Malthus believed that rising real wages encouraged earlier marriage, higher fertility and a growing population. But diminishing returns in agriculture meant that an organic economy could not keep pace. Excess labour and rising food prices drove wages down and brought population growth to a halt. Studies testing this hypothesis have focussed on the relationship between population growth and men's wages, typically overlooking women and children's economic activities and influence on demographic outcomes. New daily and annual wage series, including women and children, enable these missing actors to be incorporated into a more complete account of Malthus's hypothesis. New findings emerge: the demographic reaction to wage changes was gendered. Early-modern bachelors responded to rising male wages by marrying earlier, whereas spinsters responded to rising female wages by delaying marriage. Our evidence suggests that women played a key role in England's lowfertility demographic regime and escape from the Malthusian trap. More tentatively, we consider the demographic regime in medieval England. Although marriage was related to earnings, the size of the population was a forceful determinant of economic outcomes. While superficially similar in terms of the prevalence of late marriage and low nuptiality, this regime was consolidated by poverty and social control absent the female agency of the later era.
\end{abstract}

(207 words) 
JEL classification:

N330 Economic history: labour and consumers, demography: Europe pre-1913

Malthusian demography

Wages in Britain 1280-1860

Keywords:

Demography

Work and pay

Britain, long-run

Declarations of interest: none

\section{Acknowledgements:}

We thank the participants at the New Malthusian conference, Jesus College, Cambridge, December 2018; The Oxford-Warwick-LSE seminar, November 2019; and the LSE Economic Demography Workshop, January 2020 for insightful comments and useful steers, we particularly thank Neil Cummins, James Fenske and Jason Lennard. Additionally we would like to acknowledge the detailed comments and thoughtful consideration of this paper offered by two anonymous referees and the editor of the special issue, Toke Aidt, all of whom significantly improved and reshaped the paper. Jacob Weisdorf acknowledges the financial support from the Carlsberg Foundation (grant no. CF18.0495) 


\section{Malthus's Missing Women and Children: Demography and Wages in Historical Perspective, England 1280-1850}

\section{Introduction}

The Malthusian model of economic-demographic interactions has at its core the responsiveness of population growth to wages and of wages to labour supply. Moving beyond a state where population size was determined in the main by mortality, Malthus recognised the role of fertility, mediated by marriage and itself affected by the wage. For England, empirical analysis of the Malthusian relationship has been pioneered by the Cambridge Group with their painstaking reconstruction of vital statistics covering the period 1541-1861 (Wrigley and Schofield 1981; Wrigley, Davis, Oeppen and Schofield 1997). Mapping change in men's real wages onto population change initially identified two stages of economic-demographic interaction: a Malthusian world in 1641-1750, when changes in male wages and population growth oscillated about a low-population equilibrium, and an escape from the constraints imposed by the organic economy in 1750-1841 when male wages and population could increase together uninterrupted (Wrigley 2010, ch.6).

While representing a significant advance in our understanding the analysis has shortcomings. Only men's wages feature. Yet we know that women and children also worked. Their earnings contributed to household living standards and so potentially influenced demographic decision-making. Spinsters, who were at least partially independent, participated in marriage decisions, while wives who contributed economically participated in parental choices over children's human capital formation and the number of births (Cinnirella, Klemp and Weisdorf 2017, 2019; Klemp and Weisdorf 2019). Indeed, female agency has been identified as potentially important in limiting population growth in the long run through women's decisions over marriage (de Moor and van Zanden, 2010; Voigtländer and Voth, 2013; de Pleijt and van Zanden conference paper). The employment of young people in agrarian service, the supply of such employment, particularly for women, and the magnitude of the day wage, have been demonstrated as mechanisms determining the incidence of marriage (Kussmaul 1981; Smith 1981, 1999). Yet in standard accounts the demographic transition happens in the absence of women (Janssens, 2007). Similarly, children who could earn from an 
early age were assets not liabilities, considerations also overlooked in earlier tests of Malthus's hypothesis. These omissions call for a re-examination of the relevance of the Malthusian model for historical England. To this end, we use fresh data on men, women, and children's remuneration from paid work in England, 1280-1850. By extending the cast we provide new twists to the Malthusian plot.

Our analysis of the Malthusian mechanisms goes beyond the traditional focus on the day wages of workers in casual jobs to incorporate the large numbers who were employed on longer-term contracts, often working by the year. Attention to annual contracts is important in the case of female workers since it helps to separate unmarried women, who were able to take up such opportunities, from married women whose work was often more casual, restricted by married life, and paid at daily rates. We can then explore Malthusian effects depending on women's marital status: whereas changing annual wage rates might influence the timing of marriage itself, changing day rates might influence the timing of births within marriage. Although less clearly distinguishing married from unmarried men, the inclusion of annual contracts is also important in the case of male workers. Annual wages do not require additional assumptions about the number of days worked as do day rates when considering the standard of living over a year, something that has plagued studies based on casual payments until now. Our new wage data thus provide a window into household behaviour and illuminate the potentially conflicting motivations of different family members by capturing the gender and marital status-specific demographic responsiveness to changes in economic variables.

We present some striking findings. Early modern demographic behaviour was gendered. In particular, spinsters deferred marriage when their wages increased, contributing to low population pressure as their wages grew in the centuries leading up to the Industrial Revolution and contrasting with the tendency of early-modern bachelors to marry earlier as their wages grew. These opposing gender-specific effects of remuneration on the decision to postpone or advance marriage can help understand why demographic pressures were modest in England and how the economy evolved between 1600 and 1800 . Elsewhere we have demonstrated that child labour was an integral part of the pre-industrial economy (Horrell and Humphries 2019). Here we show that an increasing proportion of young workers had an adverse impact on their 
own and women's wages in those segments of the labour market where both were employed, but that men's wages were immune to these negative effects.

A further contribution extends England's demography back in time. While the Cambridge Group's data begin in 1541, our speculative reconstruction of the fertility rate back as far as 1280 provides rare insight into Malthusian relationships in medieval times. While tentative, our results indicate that economic circumstances had little influence on fertility in the medieval period, instead population increase drove down wages: a Malthusian response. However, entrenched late marriage and limited nuptiality ensured standards remained above subsistence levels from the fourteenth century. Malthus's positive check was avoided. These findings accord with recent scholarship that emphasises poverty as the prime factor limiting marriage (Bennett 2019). Our work suggests that two variants of the European Marriage Pattern occurred: a medieval one characterised by institutional regulation limiting population growth and an early-modern version where marriage responded to economic opportunity but for women as well as men

We begin by locating these relationships in the existing literature. We then introduce our remuneration data and proceed to investigate the economic-demographic relationships in the early modern and medieval periods respectively.

\section{Section 1. The economic-demographic nexus}

Malthus, writing in the late eighteenth century (1798) observed that population had the tendency to grow rapidly whereas the means of subsistence, the produce of the land, could increase only slowly. In Malthus' view the inevitable consequence of people outpacing resources was dearth and disease, which would bring population back into line with agricultural capacity, the positive check. In later writing (1803) he noted that death need not be the key arbiter between population and food supply, instead people might take it upon themselves to anticipate nature's brutality and act to forestall population growth, the preventive check. Given the limited means to control marital fertility, the main regulator for Malthus was the responsiveness of marriage to wages. If real wages rose, denoting prosperity, young people would marry earlier and so the number of children born in the couple's fertile years would rise. Conversely, depressed conditions would delay marriage and keep population growth in check. Thus the 
economy might oscillate around an equilibrium level of per capita welfare considerably above the subsistence levels implied by the positive check (see Wrigley 2014 for a full discussion of these mechanisms).

Hajnal (1965) laid out the conditions under which the preventive check could operate: family formation via the establishment of independent nuclear households; couples' prior accumulation of sufficient resources to support such households; life-cycle service ensuring adolescents' acquisition of skills and assets and the maintenance of pre-marital chastity; high proportions never marrying; and, the censure of illegitimacy. He observed the existence of such conditions and a resulting regulatory regime via marriage which he called the European Marriage Pattern (EMP) across Europe north-west of a line from Trieste to St. Petersburg, a range recently redrawn to cover North West Europe alone; northern France to Iceland and Scandinavia, encompassing England and the Low Countries.

For England the detailed and painstaking work of the Cambridge Group for the History of Population enabled construction of the underlying vital statistics. The requirement to record births, deaths and marriages in the Anglican church from 1538 bequeathed voluminous Parish records. Statistical techniques such as Generalised Inverse Projection and family reconstitution identified the contributions of mortality and fertility to total population changes (Wrigley and Schofield 1981; Wrigley et al 1997). Considerable, but sometimes opposing, shifts in adult and child mortality are evident over time, with severe mortality crises in the 1550 s and late 1720 s superimposed on this picture. But mortality played only a small part through the early modern period when changes in fertility were the main driving force underlying population change. Starting at 37.5 per thousand in 1540 , fertility followed a declining trend to a low point of 27.2 in 165 , rising to a peak of 39.3 in 1820 (Wrigley et al 1997, app. 9). A changing age at marriage was the key determinant after 1700 , although fluctuations in the proportions never marrying were more important in earlier years (Weir 1984; de la Croix et al 2019). From a high of 12.5 per thousand in 1540 the Crude Marriage Rate fell to 7.2 in 1690 . It recovered to plateau around 8.5 for the following century. In the period of demographic stagnation, 1650 to 1750 , life-cycle servanthood was at its height and played a key role regulating marriage (Kussmaul 1981). A tight labour market increased its attractions for employers while its sheltered and supervised attributes suggested its suitability for youthful employees, particularly young women. 
It was precisely these aspects, of course, that constrained youthful marriage and checked demographic expansion. Indeed, the intervening and important role of service in husbandry likely explains the inconsistency from 1680-1730, when the crude first marriage rate rose, probably prompted by growth in male wages, but women's age at marriage also increased (Smith 1981). By the nineteenth century, more frequent illegitimacy became an important factor underpinning population growth. Thanks to this work we have good insight into the mechanisms of population change and some of the underlying circumstances, but we know considerably less about the relationship to economic conditions.

Early attempts to correlate marriage events with real wage indicators were unconvincing, but more recent comparison using decadal averages derived from improved underlying wage data provide a close correspondence between the female marriage rate, the crude birth rate and the real wage (Wrigley 2004, 2014). ${ }^{1}$ As Malthus suggested, growth in the real wages of men led to earlier marriage and increased nuptiality and consequent population increase. This close association only ended when England escaped the constraints of an organic economy through her increasing use of coal and steam power so enabling economic growth and population expansion to coexist (Wrigley 2010).

This much we know. But aspects of the early modern demographic-economic nexus remain obscure and the relationship in previous centuries both opaque and contested.

As outlined above, the EMP required late marriage, considerably beyond the age at which physical maturity and sexual reproduction could occur, for men and, more crucially, women. Convention required accumulation of the assets needed to set up an independent, nuclear, household and both partners brought contributions to the table. Women were every bit as important as their male spouses in these processes. Yet authors have related male wages alone to demographic outcomes, although lamenting the absence of evidence on women's role (Smith 1981 pp.604-5; Wrigley 2014 p.28). Children's work too was overlooked and this despite their explicit incorporation into

\footnotetext{
${ }^{1}$ The male wage analysis itself relies on smoothed averages over three decades and on three disparate sources of wage data: Goldstone's (1986) series based on the ratio of agricultural to industrial prices 1541-1700, the Phelps-Brown and Hopkins (1962) data on craftsmen in the building industry 1700-1780, and Feinstein's (1998) series for all workers, including women and juvenile workers, thereafter.
} 
explanations advanced for the rapid population growth and the loosening of demographic constraints in early industrialisation. Protoindustrialisation and proletarianisation were both cited as forms of economic organisation which by mobilizing child labour shifted England to a higher fertility regime. While local studies have not been able to demonstrate a demographic structural break associated with these new ways of working, instead reasserting the continuation of the EMP structure within looser economic constraints, these interventions suggested the central role that family labour may play in demographic outcomes.

The importance of women's, and particularly young women's work, has been further emphasised by studies that attempt to explain the emergence of EMP itself. Instigated by the devastating mortality crisis brought about by the Black Death in England 134850 , it has been argued that labour shortage widened opportunities for young women (Goldberg 1992; Smith 1999). Their labour was better remunerated, they could exercise greater choice over their destiny, and they did so by deferring marriage. In this way they established more influence within the household when it was eventually formed: 'girl power' emerged (de Moor and van Zanden 2010). The benefits to family welfare and for female autonomy were clear, EMP was here to stay. Voigtlander and Voth (2013) offered some empirical support. The Black Death changed the land-labour ratio and so shifted agricultural specialisation away from arable (labour intensive) towards pastoral (livestock and land intensive), that is from corn to horn. Women, physically ill-suited to drive the plough as efficiently as men, had a comparative advantage in livestock production. But livestock required year-round attention best provided by live-in farm service, itself best provided by young single women. Again, the Black Death increased the opportunities and by implication the remuneration of those young women lucky enough to have survived and, given these improvements, they deferred marriage, instituted the EMP and created the divergence of the West from the rest.

These accounts have not gone uncontested. ${ }^{2}$ Young women's remuneration in service shows a paltry increase compared to that available to married women in the casual labour market (Humphries and Weisdorf 2015). Nor were young single women the only source of labour for livestock production (Edwards and Ogilvie 2018). More

\footnotetext{
${ }^{2}$ See, for example, Mark Bailey's Ford Lectures, 2019, University of Oxford.
} 
important still, late marriage and extensive celibacy were already features of the English countryside long before the Black Death (Bennett 1987; Smith 1999). Indeed, recent analysis of Weston in Lincolnshire has shown that never marrying had become increasingly prevalent among the poor from the 1270 s as there was insufficient land to support household formation (Bennett 2019). In this account the EMP was born of land shortage and associated poverty in thirteenth-century England rather than of the favourable conditions enjoyed by survivors of the plague. 3 Two very different routes to EMP have been identified.

Much then remains unknown or contested about the mechanisms by which population size adjusted to economic conditions. Many assert that from England's early history, population adjusted via the marriage system in a world of strictly limited resources to avoid Malthusian catastrophe. 4 The specific mechanisms are nuptiality and age at marriage with female agency playing a large part in these decisions. But these theories are based on limited empirical evidence. We open a new window onto this relationship. We have constructed new series on remuneration for women in annual service, for women undertaking casual work, for working children, and for men on annual contracts (Humphries and Weisdorf 2015, 2019; Horrell and Humphries 2019) which we combine with an existing series of day wages for male farm labourers (Clark 2007) to explicitly introduce women's responsiveness to economic opportunities, children's contribution to the household and engagement in the labour market, and the option of service to more closely, and realistically, examine the economic-demographic nexus. These remuneration series have been constructed on a decadal basis from 1270 to 1850 . However, reliable demographic data for England is only available from 1541 to 1850 (Wrigley et al 1997) so our initial focus is on these early modern years. As a related exercise, the wage data invite us to try to extend this analysis further back in time. Vital statistics are not readily available for $1280-1540$ so we create a possible series but note that our results are correspondingly speculative. They indicate that the early-modern relationship between demography and economy differed for the medieval period and offer a time frame for when each of the two routes to EMP were operational.

\footnotetext{
${ }^{3}$ Goldberg (1992) too finds EMP in operation in York prior to the Black Death, although he is more optimistic, relating its existence to women's opportunities in this town.

4 But see, for instance, Hatcher $(1994,1997)$ and Bailey $(1996)$, who assert the dominance of mortality events in determining medieval population size.
} 


\section{Section 2. The data: men's, women's and children's remuneration}

We present wage data for English men in annually-contracted work (Humphries and Weisdorf 2019), women in annually-contracted and casual day work (Humphries and Weisdorf 2015), and working children (Horrell and Humphries 2019) for 1260-1860. The series use data collected from hundreds of predominantly archival or printed primary sources, such as manorial, estate or household accounts, from medieval to Victorian times.5 They cover a variety of unskilled occupations counting 6017 observations of women's pay, 6800 cases for men, and 3873 observations for children. In collecting our data, we noted occupations, periodicity of payment, broadly annual or day rate (casual), region, and year. In addition, for children, we recorded their gender and age, and whether they were working with an adult. We also collected information on payments in kind, specifically whether the individual was boarded, lodged and clothed. These were important supplements especially for workers on longterm contracts so they were monetised and added to the cash wages.

For all workers, we focus on real wages on an annual basis, that is, what a person might consume from his/ her work on any representative day in the year. In line with recent literature, we use the welfare ratio approach pioneered by Robert Allen (2010) which captures real earnings by deflating annually earned income by the cost of a daily consumption basket (the so-called Allen basket) multiplied by 365 days. For day workers, this involves an assumption about the number of days worked over the year, conventionally fixed at 250, a fragile supposition in the light of mounting evidence that the working year varied from as little as 140 days in the medieval era to well over 300 in the age of industriousness (Allen and Weisdorf 2011, Humphries and Weisdorf 2019, Voth 2000). However, we retain the 250 day assumption as it keeps us in tune with the current literature, but we note that this assumption probably results in an overestimate of the welfare ratios earned by workers on day wages in the early decades of the study, during the so-called post-Black Death 'golden age' of labour, while underestimating welfare ratios for such workers later on (Humphries and Weisdorf 2019). For workers on annual contracts the necessity of making such an assumption is

\footnotetext{
${ }^{5}$ Further detail on sources is available in Humphries and Weisdorf (2015), Humphries and Weisdorf (2019) and Horrell and Humphries (2019).
} 
removed; we know their annual earnings so can simply divide this sum by 365 times the cost of the Allen basket in order to obtain an average day's pay. Indeed, the circumvention of dangerous assumptions about working time motivated the construction of the annual series. Consistent with the welfare ratio approach, we use the changing costs of Allen's 'respectability' basket to impute values to board, lodging and other perquisites received mainly, but not exclusively, by annual workers. For children we recalibrate the historical cost of living according to their needs, allowing one half an Allen basket where they receive in-kind payments. ${ }^{6}$

Elsewhere we have considered whether the Allen basket provides a consistent measure of perquisites. The value given to the basket was checked against cases where the value of male earners' in-kind payments, such as grain liveries, could be extracted from the sources (Humphries and Weisdorf 2019, p.2874, fig. 1) and children's board was additionally calculated using the price of obtaining 1500 kcal per day from wheat (Horrell and Humphries 2019). The comparisons were reassuring. In both cases the basket methodology captured a defined and realistic level of subsistence provided by non-pecuniary payments. It remains possible that payments in cash and in-kind were positively correlated: when labour was scarce, monetary payments increased and so the amount, quality and variety of food provided in-kind could have also improved. Conversely, employers may have resorted to providing just bare-bones subsistence when cash wages were low. Humphries and Weisdorf (2019, pp.2874-6) test the sensitivity of the male remuneration series to varying the in-kind remuneration procyclically with cash wages and demonstrate that the downturns and take-offs identified in their data would simply have been accentuated if this covariance existed.

Given the heterogeneity and relatively small sample sizes within groups once they are subdivided by gender, occupation, age and region, we regress the children's welfare ratios on a series of decade dummies and conditioning variables to capture variation over time (Horrell and Humphries 2019). For illustration, our child in figure 1 is a tenyear-old boy working in agriculture on day pay in the south east of England. Similar regression analysis controlling for occupational and spatial variation yields the decade averages for men's annual payments (Humphries and Weisdorf 2019). The evolution of welfare ratios over time for each type of individual, that is, their annual

\footnotetext{
${ }^{6}$ Full details are given in the constituent articles.
} 
remuneration relative to the cost of consuming one Allen basket per day in the year, is shown in Figure 1.

Figure 1.

Remuneration of men, women and boys paid annually or by the day, all expressed as the number of Allen respectability baskets that can be afforded from work per day in the year (welfare ratio).

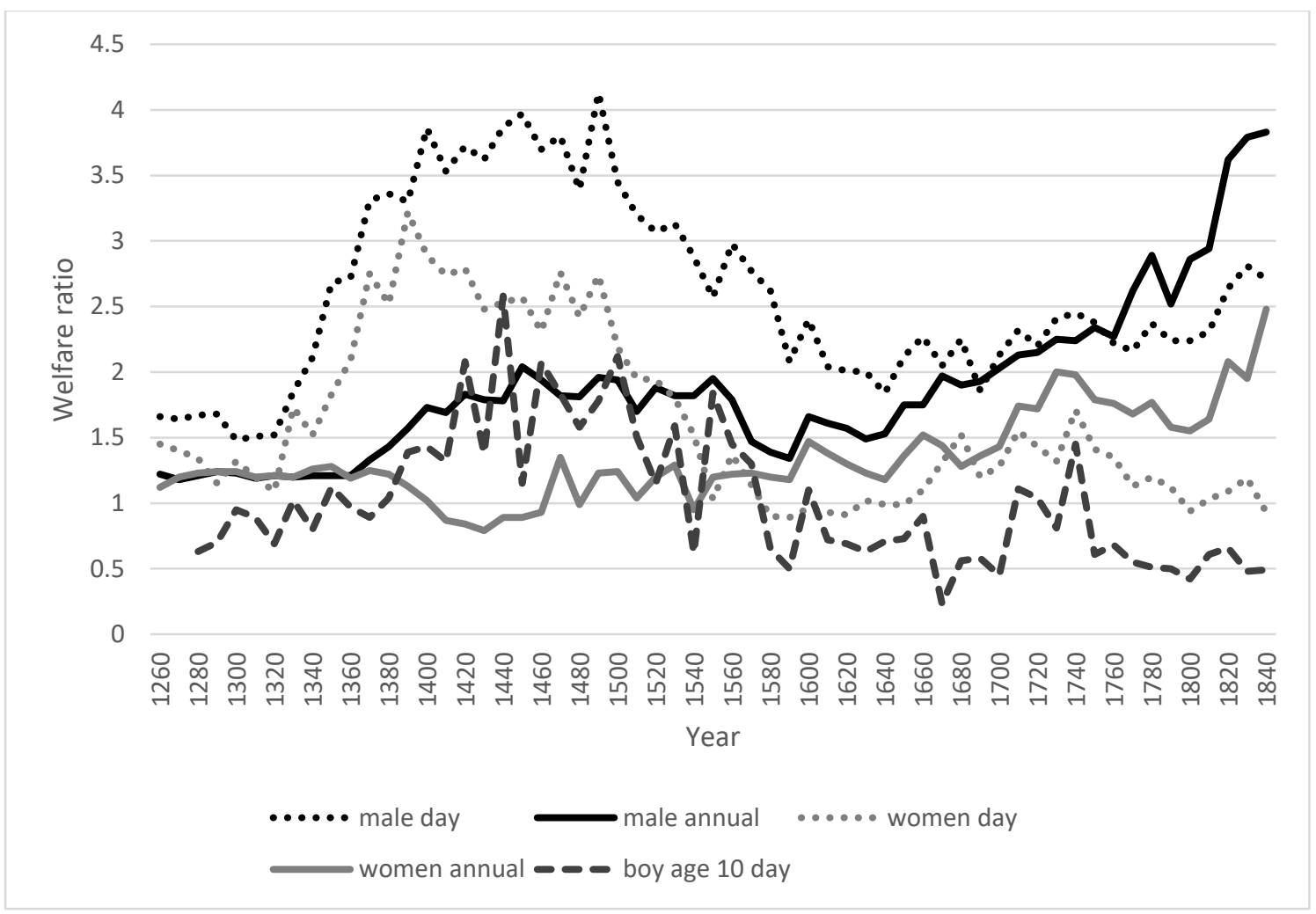

Sources: welfare ratios for male day workers are taken from Clark's (2007) series for farm labourers, converted into welfare ratios (Humphries and Weisdorf 2019, App. A.2). Male annual workers (Humphries and Weisdorf 2019, App. A.2). Female day and female annual workers (Humphries and Weisdorf 2015, App. A. ). The boy's welfare ratio is computed from the appropriate coefficients from the regression equation for children's remuneration (Horrell and Humphries, 2019, App. C.1, standard of living on a day in the year). For day workers we assume 250 days to be worked in the year throughout. 
Most workers benefited from the labour shortage that followed the Black Death, but over time these gains were eroded. There was a short-lived improvement in the first half of the eighteenth century, contemporaneous with early-modern growth, but stagnation thereafter.

Comparison of the trends by length of service is instructive. In the medieval era, male workers on day rates seemed most able to exploit the labour shortage. More plausible assumptions about the length of the working year would dampen these gains as most medievalists believe that day work was neither available nor wanted for 250 days in the year (Hatcher, 2011). In contrast, the lengthening work year of early industrialisation suggests that grossing up day rates by a factor of 250 leads to underestimation by the late eighteenth century. Remuneration on annual contracts arguably represents a more accurate account of trends in men's real earnings, capturing an equalisation of pay through choice over days of work underpinned by labour market arbitrage (Humphries and Weisdorf 2019).

For women the story is different. Women on annual contracts did not share in the golden age. These workers were predominantly single women unencumbered by children and domestic responsibilities and so able to reside with employers. Such women were coerced into service where their wages were more easily contained though the Statute of Labourers (Bennett 2010). Single women's independence was thought socially disruptive and individually disreputable. They were barred from day labour which typically became the preserve of married women who often worked alongside their husbands or other family members (for a detailed discussion see Humphries and Weisdorf 2015; Whittle 2015). In this segmented labour market, female servants' experience casts doubt on the thesis that the economic aftermath of the plague enhanced women's economic status and authority within the household.

Gaps in remuneration for annual and day workers narrowed in the sixteenth and seventeenth centuries, with implications for an increasing length of the working year and the early advent of industriousness driving economic growth. Industrialisation brought new dynamics. In the nineteenth century, men gained at the expense of women and children and the ability to work more or less continuously on an annual contract (which men could but women with children usually could not) was increasingly rewarded. 


\section{Section 3. Men's, women's and children's wages and the demographic context, 1541-1860}

\subsection{Identification method}

Economic-demographic interactions are notoriously difficult to untangle. Feedback effects from wages to population make identifying the effects of labour supply on wages, and vice versa, intractable. In the simple two equation representation of the Malthusian model below, where $\mathrm{w}$ represents the wage and $\mathrm{P}$ population, identification rests on the ability to distinguish shocks to or variables affecting one equation and not the other (Foreman-Peck 2016).

$$
\begin{aligned}
& \mathrm{w}_{\mathrm{t}}=\mathrm{a}-\mathrm{bP} \mathrm{t}+\mathrm{ut}_{\mathrm{t}} \ldots \\
& \mathrm{P}_{\mathrm{t}}=\mathrm{c}+\mathrm{dW}_{\mathrm{t}-1}+\mathrm{vt}_{\mathrm{t}}
\end{aligned}
$$

However, the Malthusian interactions are sequential not simultaneous. Within the relentless machinery of the Malthusian system, but over time, young people work then marry, children are born, dependency rates change, age at starting work adjusts, children's wages are affected, segmented child labour markets bleed into men and women's labour markets, and, eventually, adults' wages are affected. We exploit these lags in an identification strategy and utilise our remuneration data which reflects labour market opportunities by age and gender.

The flow diagram (figure 2) shows how we expect demographic variables and labour market variables to interact. Specifically, following Malthus, young people on annual contracts will marry younger, increasing the crude marriage rate, if there are favourable economic conditions and their wages are high. Increased nuptiality will have its effect through fertility on the proportion of o-4 year olds in the population. It is possible that a rapid collision with a Malthusian barrier could occur if population growth causes food prices to increase and the real wage (for the now-married men and women on casual wages) to decrease. But historically children were not entirely dependent. Children worked, but in a Malthusian world they too faced diminishing 
returns. So it is more likely that, when these children reached the ages of 5-14 and entered the labour market, we see the effect both on their own wages and those of their parents. The first order effects of population growth are manifest in an over-stocked child labour market, and assuming some segmentation from adult labour markets, it is children's wages that lead the eventual general decline. Families may respond to lower child wages by increasing child participation, through both more and younger children working (Basu 1999). These responses will exacerbate the glut, further reduce children's remuneration and hasten a return to Malthusian stagnation. At a slightly older age (15-24) these adolescents may enter service, with oversupply being predicted to reduce the wage of annual workers with concomitant effects on their marriage rates and resultant fertility, although other factors, such as the state of the economy and aggregate demand, will come into play with increasing force here.

We combine the long-run series for men's and women's wages in both annual and day labour, along with children's wages, with demographic data from the work of Wrigley et al (1997, App.9, pp. 614-15) for 1541-1860 to explore the interactions between demographic and labour market responses. The demographic variables of interest are the Crude Marriage Rate, Crude Birth Rate, share of population aged o-4 years old, share aged 5-14 years old, and share aged 15-24 years old. The demographic data is presented for quinquennial years, but we use averages for each decade to match the periodicity of our wage data. 7

\footnotetext{
${ }^{7}$ The demographic data is for the aggregate population whereas our wages relate to working families only, the different constituents will introduce further noise into the estimation.
} 
Figure 2. Flow diagram: demographic and wage effects
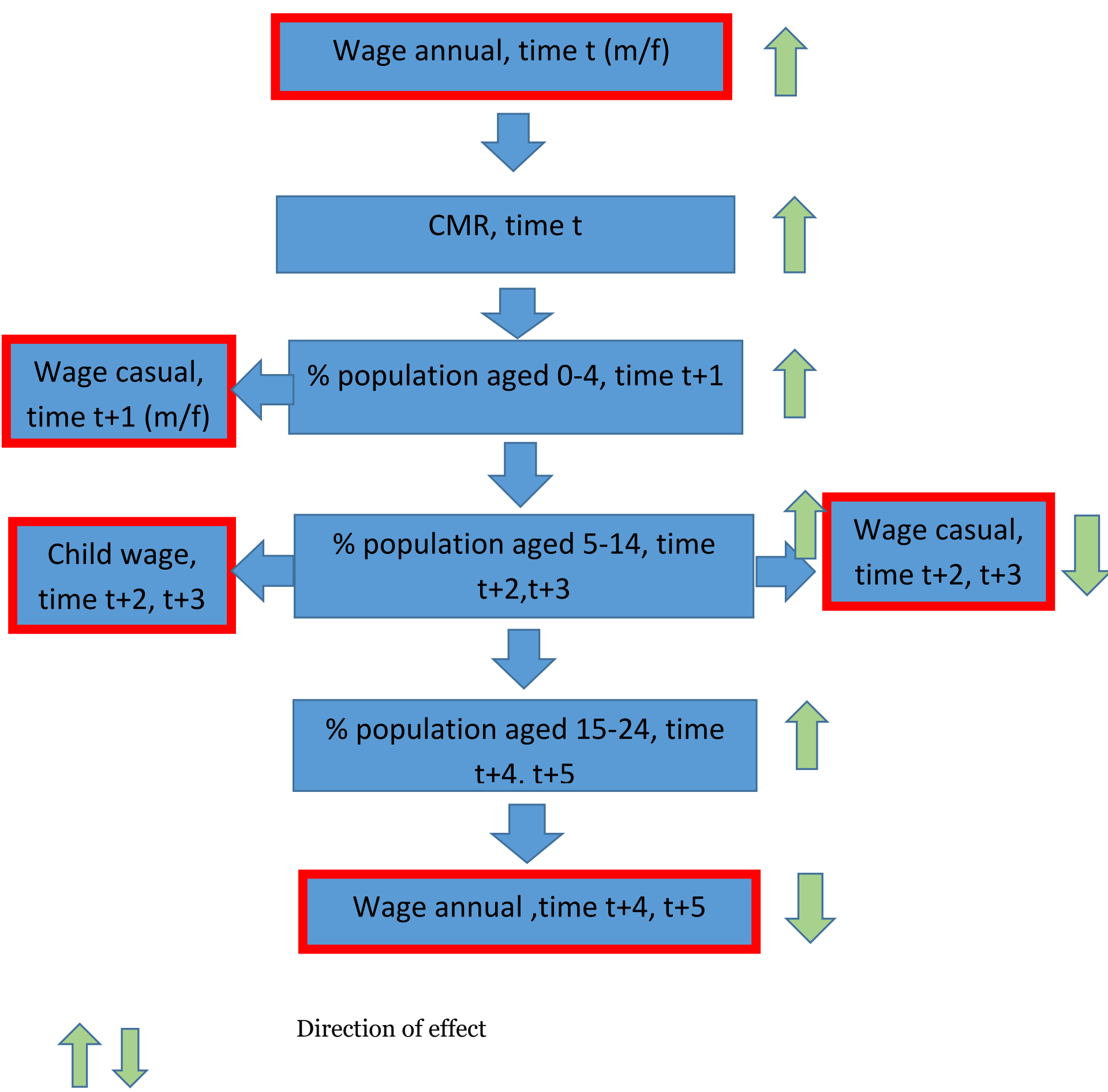

Direction of effect

Wage variables

Time in quinquennial periods 
Over the course of the 'long eighteenth century', as a consequence of population growth, the population became dramatically younger. Between 1676 and 1826 the proportion of children (o-14) rose from 29 per cent in 1676 , to almost 40 per cent by 1826 (Wrigley and Schofield 1981, p.217; Wrigley et al 1997, pp.614-5). We use the juvenile dependency rate, those aged 5-14 as a percentage of the population, as our index of population pressure on the grounds that it is independent of current wage levels: the share of juveniles in the population is the result of behaviour 5-14 years earlier and so largely exogenous to current wages.

Identification remains problematic when estimating the effect of an increased share of children in the population on adult pay. But, as we are considering pay for casual work, the preserve of those already married, such an effect would have to operate through fertility (stopping and spacing behaviour) within marriage. There is recent evidence for this link (see Cinnirella et al. 2017, 2019) but it would take time to impact the share of children and adolescents.

Our wage data is expressed in terms of the welfare ratio obtained on a representative day of the working year. We draw a demographic distinction between the two types of work arrangement, annual and casual. Workers on annual contracts, which can involve annual or quarterly pay and usually included board and lodging in the remuneration, were disproportionately young people who were found in positions such as domestic service, farm service and apprenticeship. We assume that annual wages influenced decisions about marriage, the starting point of births, while casual day rates influenced decisions within marriage, notably the spacing of births. We are confident that this partition works particularly well for women; married women were usually barred from live-in service while single women were systematically discouraged from casual employment (see Humphries and Weisdorf 2015). The relationship was much looser for male workers. Married men could undertake annual service, while single men could work on day rates without social condemnation. Men's mobility across the sectors of the labour market drove convergence of wages on annual and casual contracts (see Humphries and Weisdorf 2019). Indeed, our results indicate that the two wage series for male workers can often times be used interchangeably once adjustment has been made for the length of the working year for their influence on demographic outcomes. 
The heterogeneity of the children's wage data requires that we estimate demographic effects on children's wages using the full sample regression for the truncated time period with the teenage population share variable included (see appendix A.2). For adults, we use simple regression analysis on remuneration identified by gender and age with demographic data to explore each stage in the process.

\subsection{Results}

We first investigate the demographic impact on marriage of changes in the wage rates likely most relevant to young people's decisions, real wages from annual work. Investigating the effect of men's and women's pay separately revealed that higher pay for women in service was negatively and significantly related to the Crude Marriage Rate (CMR). ${ }^{8}$ However, men's and women's annual remuneration is collinear so incorporating both in the same regression yielded uncertain results (table 1, column 1). 9 Therefore to include both men's and women's pay we cross-substitute annual and day pay rates (columns 2 and 3).10 There is no collinearity between annual and casual remuneration or between male and female casual pay. Where single women's wages were high they deferred marriage, as predicted in the 'girl power models' described above $\left(\mathrm{p}^{*}\right)$. Although there is sometimes a negative effect for male annual workers this is not significant, instead male day rates had a positive effect on marriage. This is consistent with our claim above that for men there was mobility between the sectors with arbitrage in remuneration, so that any improvement in annual pay was matched in the casual labour market and men did not have to forgo marriage (reducing fertility) to enjoy gains. Men had options in both labour markets and, for them, higher wages in casual work encouraged marriage, as predicted by Malthus. Indeed, day wage rates may more effectively capture men's perceived ability to maintain a family after a

\footnotetext{
${ }^{8}$ Coefficient -1.063 (standard error 0.58). Male annual pay had no significant effect: -0.263 (0.297).

${ }^{9}$ Male and female annual pay had a Pearson correlation coefficient of 0.813 , significant at the $1 \%$ level. Other series were uncorrelated, with the exception of male day and male annual pay, which had a low correlation coefficient, 0.345 , but was significant at the $6 \%$ level. The Variance Inflation Factor performs a more robust test of collinearity by regressing each dependent variable against the remaining dependent variables. VIF greater than 5 indicates collinearity. Only male annual and female annual pay yielded results above this threshold (6.45 and 5.95 respectively), again indicating a degree of collinearity between these variables. ${ }^{10}$ Stepwise regression offers an alternative way to determine relevant variables. This method also identified column (3) as the preferred specification.
} 
marriage had taken place. The CMR, unsurprisingly, is a clearly significant determinant of the proportion of the population aged o-4 (column 4). Inclusion of a dummy variable for the years from 1700 onwards to capture Weir's (1984) finding that nuptiality, rather than age of marriage, was the main driver of fertility before 1700 revealed no significant effects in the CMR regressions but was positive and significant in the effect of the marriage rate on the proportion of the population aged $0-4$. We interpret this as reflecting the increase in illegitimacy as industrialisation progressed (Wrigley 2004).

Table 1. Regression results for initial demographic interactions: crude marriage rate

\begin{tabular}{|l|l|l|l|l|}
\hline & CMR & CMR & CMR & $\begin{array}{l}\text { \% } \\
\text { population } \\
\text { o-4 (t) }\end{array}$ \\
\hline & $(1)$ & $(2)$ & $(3)$ & $(4)$ \\
\hline $\begin{array}{l}\text { Welfare ratio, } \\
\text { men annual }\end{array}$ & $\begin{array}{l}0.485 \\
(0.51)\end{array}$ & $\begin{array}{l}-0.270 \\
(0.21)\end{array}$ & & \\
\hline $\begin{array}{l}\text { Welfare ratio, } \\
\text { female day }\end{array}$ & & $\begin{array}{l}0.512 \\
(1.11)\end{array}$ & & \\
\hline $\begin{array}{l}\text { Welfare ratio, } \\
\text { male day }\end{array}$ & & & $\begin{array}{l}2.723 \\
(0.62)^{* * *}\end{array}$ & \\
\hline $\begin{array}{l}\text { Welfare ratio, } \\
\text { female annual }\end{array}$ & -1.861 & & -1.533 & $(0.51)^{* * *}$ \\
\hline CMR & $1.43)$ & & & $\begin{array}{l}0.398 \\
(0.20)^{* *}\end{array}$ \\
\hline Constant & 10.322 & $\begin{array}{l}\text { (1.501 } \\
(1.17)^{* * *}\end{array}$ & $\begin{array}{l}4.520 \\
(1.12)^{* * *}\end{array}$ & $\begin{array}{l}9.542 \\
(1.75)^{* * *}\end{array}$ \\
\hline & & & & 0.096 \\
\hline Adjusted R ${ }^{2}$ & 0.073 & -0.032 & 0.589 & 0.096 \\
\hline F & 2.18 & 0.537 & $22.474^{* * *}$ & $4.303^{* *}$ \\
\hline Sample & 30 & 30 & 30 & 31 \\
\hline
\end{tabular}

Robust standard errors in parentheses. Significance at $10 \% *$, $5 \%$ **, and $1 \%$ *** $t$ refers to decade of observation

A further check on the relationship between wages and fertility can be conducted by considering the age of marriage. To this end, we use the family reconstitution data collected from English parish registers and assembled by the Cambridge Group (Wrigley et al. 1997). ${ }^{11}$ These data include the dates of birth, marriage, and death of

${ }^{11}$ The data is available at http://reshare.ukdataservice.ac.uk/853082 
several thousand individuals who lived and died in early-modern England. The dates of birth and marriage allow an individual's age at marriage to be estimated. Although the data start in 1541, only after 1570 are there enough observations for meaningful regression analysis. The data end in 1860 .

To match our wage data, we have restricted our demographic sample to those occupations in the reconstitution database that according to the HISCLASS system (van Leeuwen and Maas 2011) concerned lower-skilled and unskilled workers. For men, this included various types of workmen and labourers, as well as servants and husbandmen. Women rarely received an occupational descriptor at the time, so we restricted the female sample to those women who married lower-skilled and unskilled men. For brevity we report the results for unskilled classes, but note any differences with the broader social group HISCLASS 9-12. Table A.1 appendix reports the average age at marriage of the sampled men and women by decade, figure 3 illustrates these ages and remuneration over time.

Figure 3. Age at marriage for men and women of social classes 11 and 12 and male and female remuneration, $1540-1850$

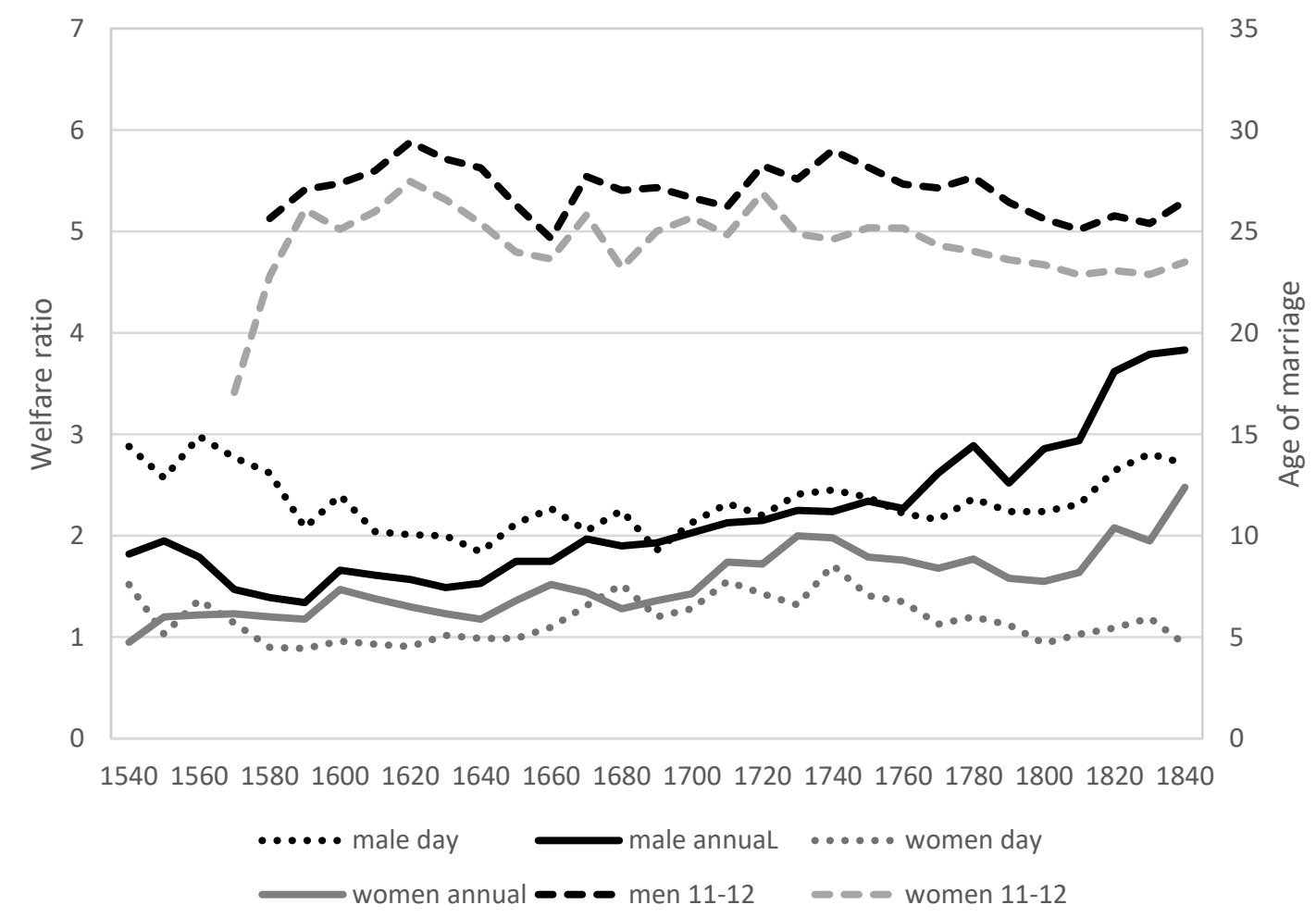


Source: Age of marriage: Wrigley et al (1997) available at http://reshare.ukdataservice.ac.uk/ 853082 .

Table 2. Regression results for initial demographic interactions: age at marriage, men and women, social classes 11 and $12 .{ }^{12}$

\begin{tabular}{|c|c|c|c|c|}
\hline & \multicolumn{4}{|c|}{ Men's age of marriage } \\
\hline Welfare ratio: & (1) & $(2)$ & (3) & (4) \\
\hline Men day & $\begin{array}{l}-3.330 \\
(0.51)^{* * *}\end{array}$ & $\begin{array}{l}-3.749 \\
(0.46)^{* * *}\end{array}$ & & $\begin{array}{l}-3.283 \\
(0.47)^{* * *}\end{array}$ \\
\hline Men annual & $\begin{array}{l}-1.17 \\
(0.52)^{* *}\end{array}$ & & $\begin{array}{l}-0.566 \\
(0.30)^{*}\end{array}$ & $\begin{array}{l}-1.237 \\
(0.51)^{* * *}\end{array}$ \\
\hline Women day & $\begin{array}{l}0.395 \\
(0.83) \\
\end{array}$ & & $\begin{array}{l}0.833 \\
(1.24) \\
\end{array}$ & \\
\hline $\begin{array}{l}\text { Women } \\
\text { annual }\end{array}$ & $\begin{array}{l}3.381 \\
(0.92)^{* * *}\end{array}$ & $\begin{array}{l}1.527 \\
(0.48)^{* * * *}\end{array}$ & & $\begin{array}{l}3.562 \\
(0.96)^{* * *}\end{array}$ \\
\hline Constant & $\begin{array}{l}31.31 \\
(1.61)^{* * *}\end{array}$ & $\begin{array}{l}33.08 \\
(1.24)^{* * *}\end{array}$ & $\begin{array}{l}27.19 \\
(1.59)^{* * *}\end{array}$ & $\begin{array}{l}31.54 \\
(1.29)^{* * *}\end{array}$ \\
\hline $\mathrm{R}^{2}$ & 0.554 & 0.431 & 0.098 & 0.550 \\
\hline \multirow[t]{3}{*}{ Sample size } & 28 & 28 & 28 & 28 \\
\hline & \multicolumn{4}{|c|}{ Women's age of marriage } \\
\hline & (1) & (2) & (3) & (4) \\
\hline Men day & $\begin{array}{l}-6.811 \\
(2.21)^{* * *}\end{array}$ & $\begin{array}{l}-7.019 \\
(2.02)^{* * *}\end{array}$ & & $\begin{array}{l}-6.764 \\
(2.21)^{* * *}\end{array}$ \\
\hline Men annual & $\begin{array}{l}-1.131 \\
(0.69) \\
\end{array}$ & & $\begin{array}{l}-0.620 \\
(0.52)\end{array}$ & $\begin{array}{l}-0.992 \\
(0.60)\end{array}$ \\
\hline Women day & $\begin{array}{l}-0.782 \\
(0.91) \\
\end{array}$ & & $\begin{array}{l}0.573 \\
(1.08) \\
\end{array}$ & \\
\hline $\begin{array}{l}\text { Women } \\
\text { annual }\end{array}$ & $\begin{array}{l}4.934 \\
(1.66)^{* * *}\end{array}$ & $\begin{array}{l}2.769 \\
(1.38)^{* *}\end{array}$ & & $\begin{array}{l}4.488 \\
(1.39)^{* * *}\end{array}$ \\
\hline Constant & $\begin{array}{l}35.54 \\
(3.38)^{* * *}\end{array}$ & $\begin{array}{l}36.03 \\
(2.77)^{* * *}\end{array}$ & $\begin{array}{l}25.10 \\
(2.12)^{* * *}\end{array}$ & $\begin{array}{l}34.93 \\
(3.11)^{* * *}\end{array}$ \\
\hline $\mathrm{R}^{2}$ & 0.645 & 0.599 & 0.053 & 0.638 \\
\hline Sample size & 28 & 28 & 28 & 28 \\
\hline
\end{tabular}

Robust standard errors in parentheses. Significance level $1 \%{ }^{* *}, 5 \%{ }^{* *}, 10 \% *$.

${ }^{12}$ Stepwise regressions also identify the results in column (4) as the preferred combination of variables for explaining men's age at marriage and column (2) for women's age at marriage. 
Men's age of marriage was significantly and negatively related to their own wages, both in day work and in annual service. But improvements in women's pay in annual service significantly increased men's age of marriage, in large part offsetting the decrease in age implied from improved male pay. Women's day pay had no effect. Increases in men's day pay encouraged women to marry considerably younger, whereas improvements in their own pay as single women encouraged the deferment of marriage. ${ }^{13}$

Two points are worth reiterating. First, men's options in the casual labour market, available to both single and married men, rather than their position in service was an important determinant of age at marriage for both young men and young women. Yet young women's own earnings in service acted to mitigate this effect, assuring female independence and delaying marriage when women were in lucrative work. However, women's potential earnings in the day labour market had no effect. Either uncertainty about the availability of this work or constraints imposed on labour market participation from childrearing after marriage made these rates of pay largely irrelevant. Second, and hitherto unrecognised, is the cross-effect of women's pay on men's age at marriage. Marriage was a joint decision based, at least in part, on economic variables and in which women's circumstances, as well as men's were significant determinants of timing. Women's economic opportunities were important factors in determining their status, providing them with leverage over their marital fate, serendipitously at the macroeconomic level they could help keep population and resources in step.

We use the results in tables 1 and 2 to consider the magnitude of these wage effects for population dynamics from the sixteenth century. From 1540 to 1640 male real day wages fell by 36 per cent, whereas those for women on annual contracts rose by 24 per cent (based on the data on welfare ratios underlying figure 1). At the same time the CMR fell by 42 per cent (Wrigley et al 1997, pp.614-15). The male wage effect alone would only account for 53 per cent of this fall, while female wage changes accounted for a further 7 per cent (coefficients column (3) table 1). The contribution of responsiveness to women's pay is more pronounced if we consider the years 1690 to

\footnotetext{
${ }^{13}$ For the wider population of lower skilled and unskilled men and women, age at marriage was affected in similar ways, with the exception that men's day rates were the only determinants of men's age at marriage for this class.
} 
1840. Over this later period the CMR rose by 17 percent, male real wages rose by 31 per cent and, on their own, would have caused CMR to rise by a massive 32 per cent, far above the level actually reached. The 82 per cent rise in women's real annual pay was the counterbalancing factor, this caused CMR to fall by 24 per cent, moderating the impact of real wage rises for men and keeping population growth more closely in line with economic resources.

Similar influences can be seen on the change in age at marriage. We take sub-periods when considerable movement in the age at marriage was evident (app. A1). Between 1590 and 1620 there was a 2 year 4 month rise in age at marriage for men in unskilled occupations, alongside a one year 4 month increase in marriage age for women of the same social class. Men's real wages moved relatively little over this period, day wages decreased by 3 per cent, while annual pay improved by 17 per cent. For men the two effects counterbalanced one another, leaving a negligible effect on men's age at marriage. ${ }^{14}$ Responsiveness to the 10 per cent increase in women's annual pay is required to explain at least some of the rise in men's marriage age, this caused them to marry five months older than they had previously. Men's day pay also influenced women's age at marriage, increasing this by some 6 months, but women's responsiveness to their own pay explains a further 4 months of the increase observed. For the same social groups, the evidence records a 2 year 10 month fall in age at marriage for men alongside a 4 year decline for women between 1720 and 1830. Over this period welfare ratios rose by 28 per cent for male day workers, a massive 76 per cent for male annual workers, but a rather smaller 13 per cent for female annual workers. The male wage increases taken together would suggest a 4 year decline in men's age at marriage, but the delaying effect of a rise in women's pay in annual service mitigated this fall by 10 months. Men's day wage improvements would also have prompted women to marry 4 years and 4 months younger, but women's responsiveness to the very much smaller rises in their own wages acted to partially offset this and raised their marriage age by 8 months.

These examples illustrate the important effects of wage changes on demographic outcomes, highlight the significant role played by changes in single women's pay, and

\footnotetext{
${ }^{14}$ Coefficients taken from table 2 column (4) for men and column (2) for women. The effects on marriage age from women's annual pay would be considerably larger if the coefficients in column (4) were employed, women's marriage age would be raised by 6 months in 15901620 and one year in 1720-1830.
} 
demonstrate women's work, remuneration and agency acted to keep Malthus's preventive check in operation.

Bypassing marriage rates and ages, we conclude this section by looking directly for the effect of pay on fertility (Crude Birth Rates, CBR, table 3). ${ }^{15}$ We find increased male remuneration consistently encouraged both a higher birth rate and consequently an increased proportion of 0-4 year olds in the population, whereas women's pay always had a dampening effect on both. Improvements in women's annual pay decreased the birth rate, most probably through the delaying effect on marriage, and this also reduced the size of the young population. But women's casual pay, available predominantly to married women, also had an influence. Maybe couples increased the spacing of children's births in response to improvements in married women's economic circumstances. Or, more darkly, monetary incentives for mothers to engage in paid work may have had their corollary in inadequate childcare and poor environmental conditions which adversely affected infant and child mortality. These mechanisms require further work to unravel. Key though is the fundamental relationship of good economic opportunities for men hastening marriage and encouraging population increase whilst beneficent circumstances for women constrained population growth.

Table 3. Regression results for initial demographic interactions: crude birth rate and percentage population aged $0-4$ in time period $(t)$

\begin{tabular}{|l|l|l|l|}
\hline & CBR & CBR & $\begin{array}{l}\text { \% } \\
\text { population } \\
\text { o-4 }\end{array}$ \\
\hline $\begin{array}{l}\text { Welfare } \\
\text { ratio }\end{array}$ & $\mathbf{1}$ & $\mathbf{2}$ & $\mathbf{3}$ \\
\hline Men annual & $\begin{array}{l}3.811 \\
(1.26)^{* * *}\end{array}$ & $\begin{array}{l}3.986 \\
(1.19)^{* * *}\end{array}$ & $\begin{array}{l}1.588 \\
(0.43)^{* * *}\end{array}$ \\
\hline Female annual & $\begin{array}{l}-3.943 \\
(2.46)\end{array}$ & $\begin{array}{l}-4.323 \\
(2.05)^{* *}\end{array}$ & $\begin{array}{l}-1.837 \\
(0.88)^{* *}\end{array}$ \\
\hline Men day & $\begin{array}{l}3.741 \\
(1.24)^{* * *}\end{array}$ & $\begin{array}{l}3.473 \\
(1.16)^{* * *}\end{array}$ & $\begin{array}{l}1.210 \\
(0.54)^{* *}\end{array}$ \\
\hline Female day & -1.271 & & -2.042 \\
& $(1.80)$ & & $(0.73)^{* * *}$ \\
\hline Constant & 23.700 & 23.034 & 11.760 \\
& $(3.65)^{* * *}$ & $(3.46)^{* * *}$ & $(1.34)^{* * *}$ \\
\hline & & & \\
\hline
\end{tabular}

${ }^{15}$ Stepwise regression agreed with the selection of variables in columns (2) and (3). 


\begin{tabular}{|l|l|l|l|}
\hline Adjusted R 2 & 0.533 & 0.541 & 0.579 \\
\hline $\mathrm{F}$ & $9.546^{* * *}$ & $12.803^{* * *}$ & $11.323^{* * *}$ \\
\hline Sample & 30 & 30 & 30 \\
\hline
\end{tabular}

Robust standard errors in parentheses. Significance at $10 \% *, 5 \% *$, and $1 \% * * *$

We check the robustness of these results. We re-estimate using Winsten Prais standard errors to correct for serial correlation, and these confirm the key results above (see appendix 3). We test for unit roots in the time series using Dickey-Fuller tests. Only the CMR series is found to be non-stationary. We therefore re-estimate this relationship using logarithms of the key variables (Ramey 2016). The Crude Marriage Rate continues to be positively related to male remuneration, both through day rates and annual pay in this specification, but negatively related to young women's earnings in annual service (see appendix A.3).

We now investigate the labour market impact of changes in demography. Specifically, whether more working age children affected their own pay and/or parental pay (table 4). We focus on the labour market effects of more children aged 5-14 in the population, rather than the presence of the younger age group, o-4. Although having more young children in the population may have put upward pressure on food prices and hence reduced the real remuneration of adults, reduced pay would also reduce births, as demonstrated above. However, prevailing adult wages could not determine the proportion of 5-14 years old, which is the result of behaviour some 6 to 15 years earlier, thus minimising the endogeneity problem for this group of juveniles.

Table 4. Regression results for increasing juvenile population, aged 5-14, on own and adult wages

\begin{tabular}{|l|c|c|c|}
\hline & $\begin{array}{c}\text { Welfare ratio, child } \\
\text { (coefficient from welfare } \\
\text { ratio regression, app. A.2) }\end{array}$ & $\begin{array}{c}\text { Welfare ratio, } \\
\text { casual worker, } \\
\text { male (t) }\end{array}$ & $\begin{array}{c}\text { Welfare ratio, } \\
\text { casual worker, } \\
\text { female (t) }\end{array}$ \\
\hline $\begin{array}{l}\text { Independent } \\
\text { variables: }\end{array}$ & $(1)$ & $(2)$ & $(3)$ \\
\hline $\begin{array}{l}\text { \% population } 5^{-} \\
14(\mathrm{t})\end{array}$ & $\begin{array}{c}-0.019 \\
(-2.418)^{* * *}\end{array}$ & $\begin{array}{c}0.088 \\
(0.02)^{* * *}\end{array}$ & $\begin{array}{c}-0.066 \\
(0.02)^{* * *}\end{array}$ \\
\hline Time trend & $\begin{array}{c}-0.014 \\
(-6.173)^{* * *}\end{array}$ & & 2.550 \\
\hline Constant & 1.121 & 0.498 & \\
\hline
\end{tabular}




\begin{tabular}{|l|c|c|c|}
\hline & $(6.075)^{* *}$ & $(0.48)$ & $(0.44)^{* * *}$ \\
\hline Sample size & 3243 & 30 & 30 \\
\hline Adjusted R 2 & 0.420 & 0.174 & 0.169 \\
\hline F statistic & $66.281^{* * *}$ & $7.326^{* * *}$ & $7.109^{* * *}$ \\
\hline
\end{tabular}

Robust standard errors in parentheses, t-ratio for children's wage regression. Significance at $10 \% *, 5 \%$ *** and $1 \% * * *$

The effect of an increasing child population of working age (5-14 years) had an inverse relationship with their own remuneration (column 1, calculated from regression on full sample of children, see appendix A.2), oversupply in the child labour market acted to depress children's pay. The relationship of an increased proportion of older children (5-14 year olds) with married men's and women's remuneration finds a positive impact on adult male remuneration, while married women's casual pay was reduced (columns 2 and 3). We suggest that adult men largely operated in a different part of the labour market to children. A greater supply of juvenile workers may have increased the relative value of physically more productive and scarce adult labour. Additionally, if more young workers were available to work alongside and assist adult males, adult productivity and so pay increased. However, children competed for similar low- and semi-skilled jobs with women and oversupply in this segment of the labour market acted to depress married women's pay.

What do these observations allow us to conclude about the early modern labour market and the operation of Malthusian constraints in the economy? First and foremost, while the analysis supports the Malthusian claim that marriage and fertility were related to the real incomes young people could earn, it also presents a gendered sub-plot which is crucial for understanding how England negotiated the postMalthusian phase. In particular, high wages for young women occasioned delayed marriage and reduced fertility, possibly because young women valued their independence. Instead, traditional Malthusian effects appear to have operated through male earnings.

The tendency for improvements in men's and women's labour market positions to operate in opposite directions on marriage and fertility decisions emphasises the important role of women in demographic history and the dangers involved in 
overlooking female agency. Furthermore, as male and female wages themselves often move in the same direction, albeit not to the same extent, the effect of male wage improvement in increasing fertility may be counterbalanced by female desires to be unencumbered and to continue to earn high wages. These countervailing gendered effects on fertility may have cancelled out, leaving scholars fixated on the male wage with the impression that preventive checks were negligible despite the fact that England was able to maintain some of the highest wages in the early modern epoch (Allen 2001). Once separated out, small changes in demography may be the consequence of a large preventive check representing male desires for marriage and children when wages are high, offset by women deferring marriage and fertility until a later point in life. Furthermore, there is no evidence that the economy readily ran up against Malthusian constraints. More children did not reduce men's wages; apparently the early modern economy was able to accommodate some population growth.

What also emerges from this discussion is the extent to which early modern labour markets were segmented to the disadvantage of women, particularly married women. They were not protected from a growing labour supply by skills or the ability to move in search of work, and so often remained trapped in low- and semi-skilled jobs. This segment of the labour market was flexible, characterised by an inverse relationship between supply of labour and pay and ease of entry which left women susceptible to substitution by cheaper, and maybe more productive, young people. By-and-large, economic-demographic interactions moved beyond Malthus' imaginings in the period 1541-1860.

\section{Section 4. Men's, women's and children's remuneration and demography, 1270-1540}

\subsection{The medieval context}

The existence of the European Marriage Pattern in England from 1540 is not in doubt but pinning down the key mechanisms behind medieval demography has proved elusive. In grand narratives, the Black Death has been identified as the shock to population dynamics that shifted the demographic regime. Initially characterised by over-population, near-subsistence living standards, mortality-driven changes and 
Malthus's positive check, the plague brought with it a beneficent environment where improved land to labour ratios increased living standards and a new balance was struck where higher welfare levels were maintained through limited and late marriage. Low fertility and Malthus's preventive check became the norm (de Moor and Van Zanden 2010; Voigtlander and Voth 2013). Essentially the account of the EMP which our findings confirm for post 1540 is extended back into the past and linked in origin to the cataclysm of the Black Death. Elements of this account have been challenged. Although based almost entirely on evidence subsequent to 1500, Dennison and Ogilvie (2014) argued that countries outside Northern Europe exhibited stronger versions of the EMP than England, but were not blessed with resultant high economic growth. Indeed, women's comparative advantage in pastoral agricultural necessary to the Voigtlander and Voth model discussed above, has also been shown to be unsupported by much historical evidence (Edwards and Ogilvie 2018).

Medieval historians' detailed studies of the surviving evidence for specific locations suggest great uncertainty about the contemporaneous demographic regime. Some identify a high-fertility mechanism (Razi 1980), but focus on elite groups in which we might expect earlier and more universal marriage. Others argue persuasively that the characteristics of the EMP were in place in the century before the Black Death (Bennett 2019, Smith 1999) finding its features evident in late-medieval rural Essex (Poos 1991) and medieval York (Goldberg 1992). Low rates of nuptiality, life-cycle service, and late marriage based on the establishment of an independent household appear persistent features from the thirteenth century. More contentious is the relationship, if any, to the economy. Rather than yielding high living standards, late or no marriage was particularly characteristic of the poorer, unpropertied classes and constraints on marriage bit particularly sharply when times were hard and were associated with poverty rather than prosperity (Bennett 2019, Bailey 1996). Others observe a more congenial environment. As women's economic opportunities improved, particularly in towns, they eschewed marriage either entirely or until later in life, so undermining the potential for population pressure to erode material gains (Goldberg 1992). Kelly and O'Grada (2012) nuance these accounts through their study of the relationship between merchet payments (fines paid to the manorial lord for permission to marry) and wheat prices 1269-1348: poorer tenants deferred marriage when wheat prices were high, for wealthier tenants there was a positive association occasioned by higher incomes and the greater availability of land as impoverished tenants relinquished their holdings. 
These studies provide strong evidence that household formation was intimately related to the economy from very early on in England, so that fertility, along with mortality, was a significant determinant of population change prior to the Black Death. They also highlight the possibility of two types of or routes to the EMP: one through poverty and the social control of working people constraining household formation, age of marriage and indeed nuptiality more generally, and the other, as described for the early modern period above, operating through the female response to higher wages, enhanced economic opportunities and the chance to remain independent and single.

\subsection{Remuneration and demography in the medieval period}

Our remuneration data provide the first opportunity to investigate these relationships over the long run, shining an empirical light on the demographic mechanisms in the dark years before parish vital statistics are available. We provide three points of comparison: we establish a relationship between population size and the economy based on a mechanism that relates male and female wages in annual service and day labour to marriage and hence population movements; we consider fragmentary evidence of movements in age at marriage against our wage data; and we attempt to produce an approximate crude birth rate series for this period to examine the relationship between wage rates and fertility, as we have already done for 1540-1850.

Lawrence Poos (1991, pp.222-3) sets out a relationship between marriage rates and population pressure in his study of late medieval Essex. For many young people, both male and female, servanthood was a life-cycle phase between adolescence and marriage. But the availability of positions, relative to day labour, depended crucially on the price of wheat which, in turn, depended as much on consumption demand (determined itself by population and income levels) as on climatic conditions. Specifically, when population rose, wheat prices were high, and farmers preferred to employ day labour, to avoid the costs of providing board. Although both men and women worked in arable agriculture, men's physical advantage made them preferred for many jobs or when posts were limited. Low population pressure and low wheat prices, on the other hand, increased both the availability of land and the ability of the population to extend their consumption choices into the semi-luxuries of meat and 
dairy. Farmers strove to satisfy this demand, but pastoral agriculture required more year-round attention. Farm servants paid in large part through, now-cheaper, board provided this consistent level of service at lowest cost and annual service became preferable, particularly benefitting young women who gained work as dairy maids or shepherdesses. We extend this reasoning to encompass a predicted relationship to the annual/day remuneration ratio. With population decline, the annual/day pay ratio would also decline. ${ }^{16}$ Conversely population increase will be associated with an increase in the annual/day pay ratio. This pro-cyclical relationship is expected to be more pronounced for women than for men because of young women's greater involvement in annual service and pastoral agriculture than young men. Identifying the existence of an association between the pay ratio and population will not identify the direction of causality, but it can demonstrate that population size is related to mechanisms that invoke shifts in nuptiality and fertility in relation to the economic environment and opportunities, rather than being driven exclusively by mortality.

Our data provide this annual/casual wage ratio for both men and women for the medieval period. Population figures for England are taken from Broadberry et al (2015, pp.238-9) for 1280-1540, indexed at 5.2 million in 1700. ${ }^{17}$ Plotted against population the pro-cyclical relationship is apparent (figure 4) and the relationship stronger for women than for men (correlation coefficient female wage ratio to population $=0.9197$, male wage ratio 0.8378 ). The evidence here is consistent with fertility restraint through life-cycle servanthood and marriage occurrence being an important element of English population dynamics throughout the medieval period.

\footnotetext{
${ }^{16}$ To illustrate: if the annual welfare ratio stood at 1.5 (365d per year $+2 \mathrm{~d}$. basket per day) and the day ratio at 3.0 (8.76d per day x250 days), giving an annual/day pay ratio of 0.5 , then a reduction in population would reduce the demand for wheat, lowering the price of wheat. Price of basket say 1.5d. This would reduce the cost of board for a live in servant but would also reduce the cost of an Allen basket. For a servant, both remuneration and cost of living would decline, the former by a bit less than the latter, therefore the welfare ratio would increase to 1.67. For a day worker, assuming no adjustment to the nominal wage, only the cost of living would decrease thus giving a substantial rise to the welfare ratio to 4.o. The annual/day ratio will have declined to 0.42 . At this pay ratio there will be a higher proportion of positions for young people in service (pastoral agriculture), this will decrease the rate of marriage, and population will also decline.

${ }^{17}$ See also Broadberry et al (2010).
} 
Figure 4. Medieval population and annual/day pay ratios for men and women, 12801540 .

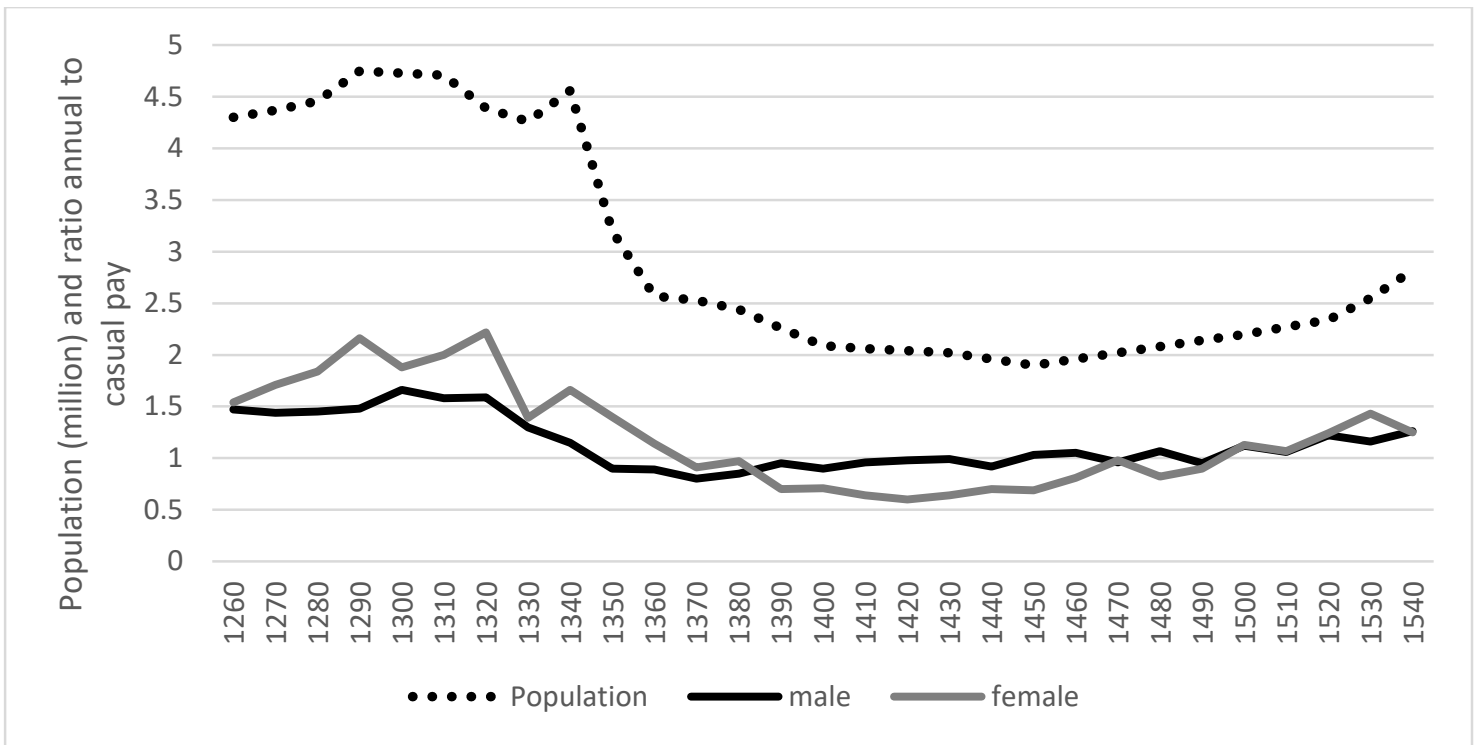

\subsection{Wages and age at marriage}

Identifying the coexistence of declining population with increased life-cycle servanthood and increased restraint on marriage leaves a question hanging. If population decline begets population decline, and vice versa, what stops the process? For population increase, Malthus's positive check might come into operation population increase would outrun food supplies and cause a rise in mortality. But was the preventive check in operation too? Within the wheat price-marriage-population mechanism operationalised via life-cycle servanthood there is a counterbalancing effect. As wheat prices decline and assuming no adjustment to the nominal wage, real wages will increase and will do so more for day workers than annual workers. Under Malthus's preventive check, this would increase marriage and so fertility and population. We investigate whether there is evidence of this countervailing tendency in operation.

The parish population studies emphasize age of marriage changing with economic conditions, the preventive check restraining population growth from depleting economic resources, at least from 1700. Prior to this, nuptiality may have been the main driver (Weir 1984, de la Croix et al 2019) and this was likely true for earlier 
centuries too (Bennett 2019). Evidence on the frequency of marriage is rare. 18 However, there have been a number of attempts to estimate age at marriage (see table 6). We plot these against our wage data (figure 5). While marriage ages offer a broad and uncertain range and only exist for a few periods, for working people, male age at marriage exhibits little variation over time. For women, there is a hint that age at marriage may have increased as female annual pay fell in the early fifteenth century. However, there is little evidence of age at marriage varying systematically despite quite significant changes over time in the real remuneration levels available to young men and young women. But if changes in age at marriage are unsure, we are more certain about levels, for late age at marriage throughout the period under study, indeed from 900 through 1600 , is implied by archaelogical evidence derived from female skeletons taken from English cemetery sites (Shapland et al 2016). Age at first menstruation is identifiable from the bone structure, as is the completion of pelvic growth that is needed for full fertility and the likelihood of conception. The first was only found for girls aged 15 or more, and the second was only evident in very few women under age 20. Furthermore, the handful of women who were buried with foetuses in utero, probably the result of hazardous first pregnancies, all had an estimated age of death of 20 or over. The authors conclude that few young medieval women would have been fertile before the age of 20 with no suggestion of changes over the whole period studied.

Overall the data provides some evidence that age of marriage was late but that it showed little variation with economic conditions, leaving life-cycle servanthood as a stronger influence on marriage and population than day labourers' wage rates.

Table 6. Evidence from existing studies on age at marriage in medieval England.

\begin{tabular}{|l|l|l|l|l|l|}
\hline $\begin{array}{l}\text { Years } \\
\text { covered }\end{array}$ & Place & \multicolumn{2}{|l|}{ Elite } & \multicolumn{2}{l|}{ Non-elite } \\
\hline $1252-1347$ & $\begin{array}{l}\text { Spalding } \\
\text { Priory a }\end{array}$ & Men & Women & Men & Women \\
\hline $1296-1345$ & $\begin{array}{l}\text { Glastonbury } \\
\text { Abbey b }\end{array}$ & & 26.1 & 21.4 \\
\hline $1280-1349$ & $\begin{array}{l}\text { Halesowen } \\
\text { Manor c }\end{array}$ & 49\% married ages 18-22 & & \\
& & & $24-29$ & \\
$(26.5)$ & & \\
\hline
\end{tabular}

${ }^{18}$ But see Kowaleski (1999) and evidence cited by Smith (1999). 


\begin{tabular}{|c|c|c|c|c|c|}
\hline $1350-1400$ & $\begin{array}{l}\text { Halesowen } \\
\text { Manor c }\end{array}$ & $\begin{array}{l}12 \% \text { by age } \\
20\end{array}$ & $\begin{array}{l}13 \% \text { by ages } \\
12-19\end{array}$ & & \\
\hline $\begin{array}{l}1348 / 9- \\
1478\end{array}$ & $\begin{array}{l}\text { Spalding } \\
\text { Priory and } \\
\text { Crowland } \\
\text { Abbey a }\end{array}$ & & & 25.5 & 24.6 \\
\hline \multirow[t]{2}{*}{$1372-1474$} & $\begin{array}{l}\text { York } \\
\text { urband }\end{array}$ & & & $\begin{array}{l}\text { Women's } \\
\text { age + } 2.9 \\
\text { years } \\
(27)\end{array}$ & $\begin{array}{l}\text { Early/mid } \\
205 \\
(24)\end{array}$ \\
\hline & $\begin{array}{l}\text { York - rural } \\
\text { d }\end{array}$ & & & $\begin{array}{l}\text { Women's } \\
\text { age }+3.8 \\
\text { years (24) }\end{array}$ & $\begin{array}{lr}\text { Late } & \text { teens/ } \\
\text { early } & 20 \mathrm{~s} \\
(20) & \end{array}$ \\
\hline C15th & London e & & 19 & & $\begin{array}{l}\text { Mid 20s } \\
(25)\end{array}$ \\
\hline $1560-1599$ & Cumbria $^{f}$ & & & 26.6 & 23.25 \\
\hline
\end{tabular}

Note: Age used in figure 5 given in parentheses

Sources: a Hallam (1985 p.59). ${ }^{\mathrm{b}}$ Martin Ecclestone (1999 pp.202-4): men with land. c Razi (1980, p.63):

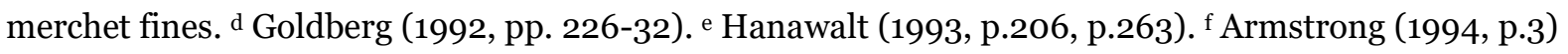

Figure 5. Estimates of non-elite age at marriage, compared with annual remuneration for young men and young women (welfare ratio)

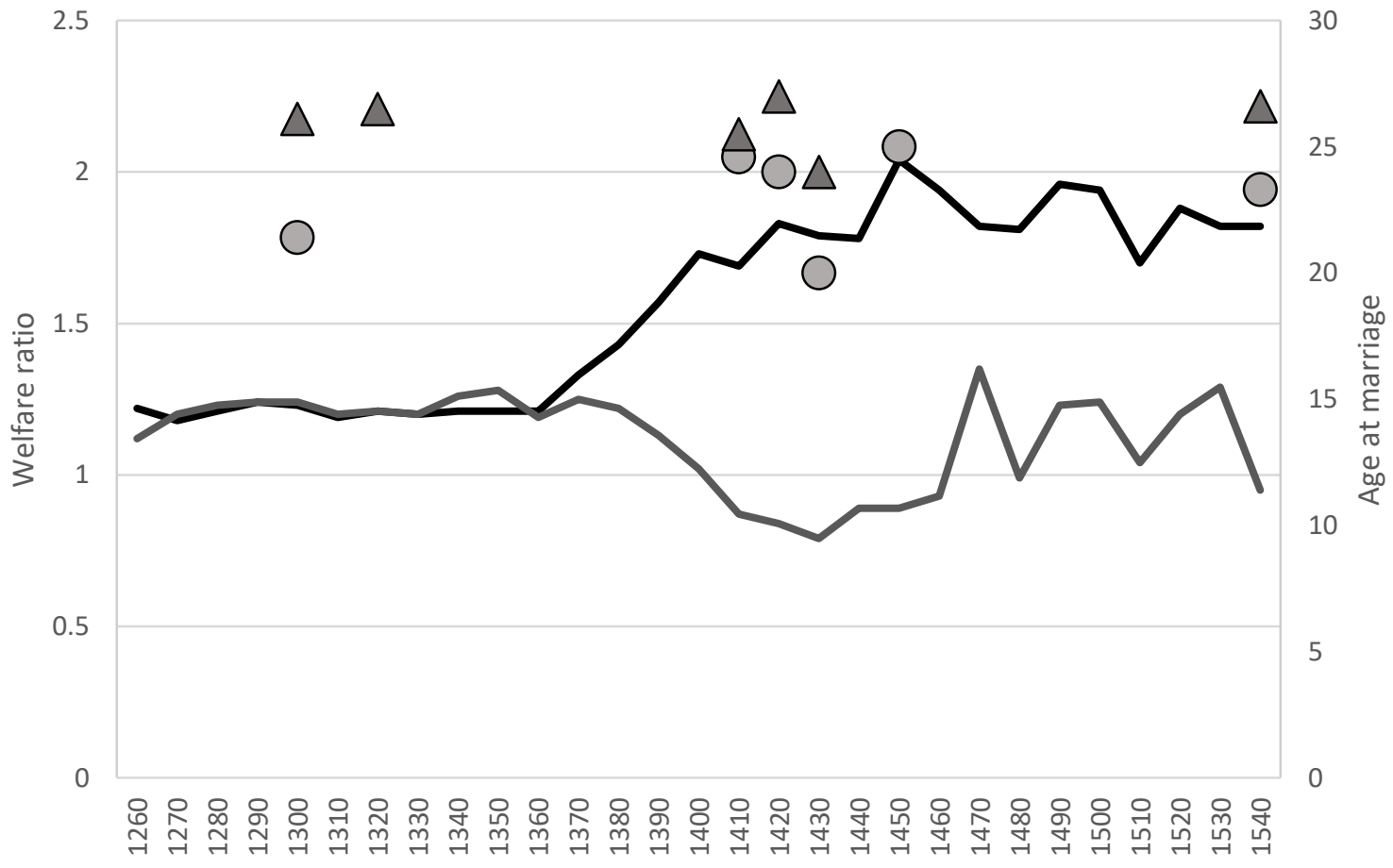

male annual $\quad$ female annual $\quad$ female age $\Delta$ male age 
Note: age at marriage uses middle of age range plotted at mid-point of time span from the evidence cited in table 6.

\subsection{Remuneration and fertility .}

The evidence so far indicates a general interaction between population size and relative wages with late age of marriage commonplace. We now push the analysis further and try to extract the relationship of male and female pay to a long-run series of demographic data, although recognise that our results for the medieval period can best be considered tentative.

To this end, we use the only long-run series of mortality evidence currently available: Pamela Nightingale's (2005) death rates of merchant creditors 1305 - 1529. This provides a consistent baseline for mortality over these three centuries. Using this information, along with the estimates of mortality from the other researchers that she cites, we approximate death rates at quinquennial intervals from 1260-1540 (see appendix A.4 for the information extracted from Nightingale's article and the death rates we then imply).

Using these death rates per 'ooo population alongside Broadberry et al's (2015, pp.226-44, app.5.3) index of population 1270 - 1545 for England we can estimate the fertility rate required to get from one quinquennial population figure to the next, given the prevailing death rate in that five-year period. ${ }^{19}$ Specifically, population in time $t$ plus births in time $t$ less deaths in time $t$ will yield population in time $t+1$, where $t$ denotes a five-year time period. Rearranging allows estimation of fertility rates from the available population sizes and death rates. We also make adjustment for infant mortality, but assume this at 18 per cent of births throughout (Davenport 2018: infant mortality about 175 per ooo in 160o). The resultant series are illustrated in figure 6 below.

19 There is debate about the size of the population before 1300. Smith (1988, p.191) considers it could be over 6 million and that it continued to decline during the second half of the $\mathrm{C}_{15} \mathrm{th}^{\mathrm{h}}$, instead of rising (Smith 2009) (both cited in Broadberry et al 2010). Alternative fertility rates were computed under these assumptions but the resultant series had more extreme values than found with Broadberry et al's (2015) population figures, so we opted for the latter in our subsequent analysis. 
Figure 6. Constructed vital statistics 1270-1540: constructed mortality rate and derived fertility rate.

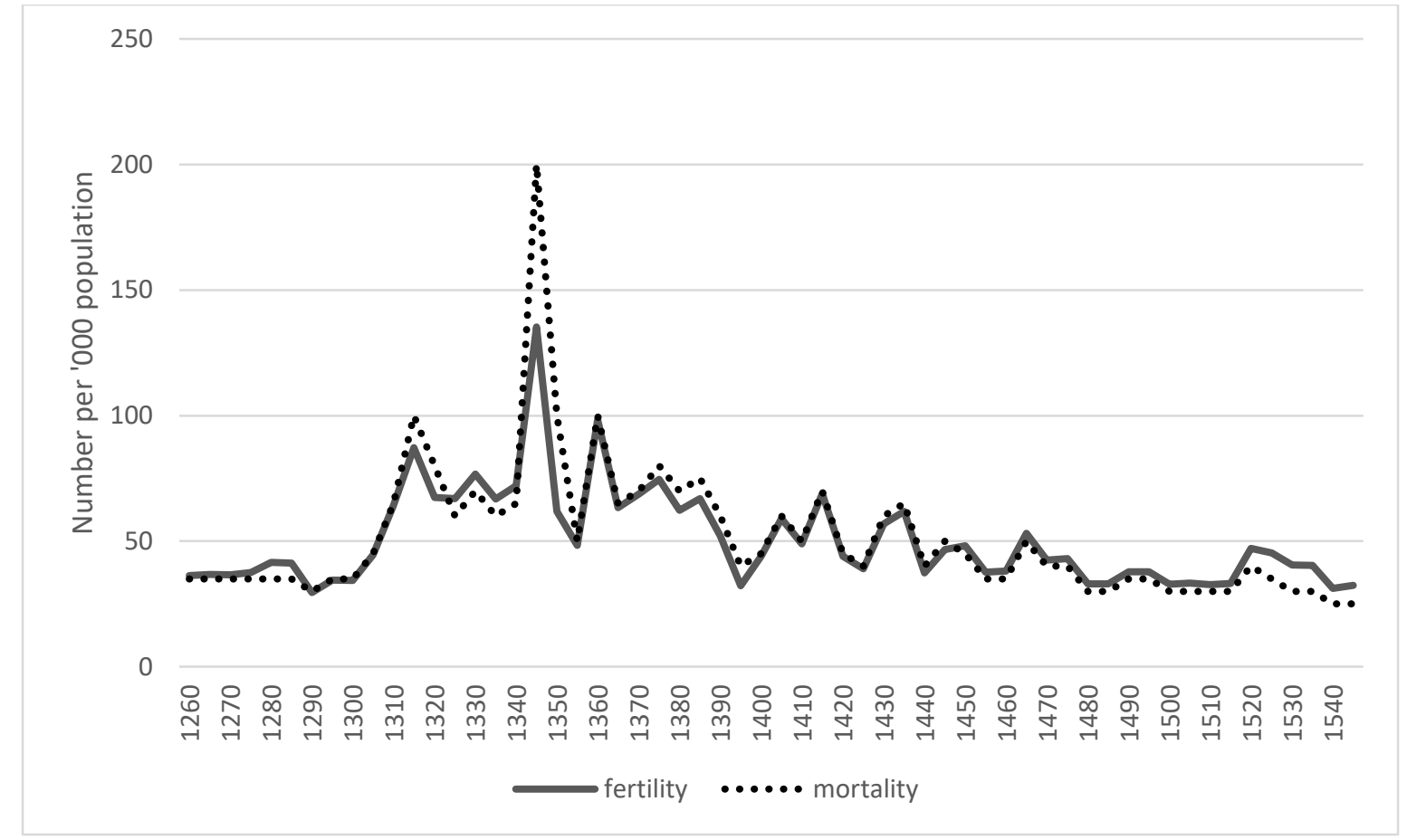

The resultant data series involve considerable margins of error, occasionally yielding implausibly large figures. This is as much a consequence of uncertain population figures as of inaccuracy in the constructed mortality rates. Although quinquennial population figures have been produced they rely on interpretation and interpolation between sparse benchmarking estimates, of which the most accurate is supplied by the Poll Tax returns of 1377. Nonetheless, for much of the series the estimates are within plausible ranges.

From 1541-1871 population grew from 2.83 million to 21.5 million, crude death rates were between 20 and 30 per 1000, but reached 40 in 1556, and crude birth rates ranged from 20 to 40 per 1000 with most in the 30s. The earlier data, 1270-1540, fits in predictable ways with these numbers. Crude death rates were generally higher but, in a number of years, were as low as the 25 or 30 seen later; crude birth rates were also higher at 40 to 55 in general. There are some obvious peak years: death rates were higher in the 1300 s and 1400s, reaching 100 in the famine years of 1315-19, 200 in the Black Death years of $1345-49$, and 100 in the subsequent plagues of the 1360 s and $1370 s$. We construct a dummy variable to reflect these demographic crisis years for use 
in the subsequent analysis. ${ }^{20}$ Our fourteenth and fifteenth century fertility rates lie above the 30 per thousand that Poos (1991 pp.124-5) constructs from churching records for medieval Essex, but he notes these are at the levels observed in the late seventeenth/ early eighteenth century demographic depression, higher rates therefore seem reasonable. Even so, there are implications that follow from these high birth and death rates that should be drawn out. Specifically, very high fertility rates would require young age at marriage and near universal marriage, conditions that would contradict the characteristics of EMP. But note that the fertility rates postulated here are estimated for the whole English population, not just the labouring element for which we have constructed wage series. Evidence exists for young marriage of higherranking social classes (Razi 1980) and increases in their nuptiality when conditions were unfavourable to the unions of wage earners and labourers (Kelly and O'Grada 2012). Thus base-line fertility may indeed be high but not necessarily preclude responsiveness of marriage rates to economic conditions by the poorer segments of society. Since there is variation in our fertility series over time we are encouraged to proceed to consider the relationship with economic variables. We average the fertility rates for each decade for comparison with our decadal wage data, as previously.

Inspection of the constructed fertility series against the male and female annual payment series shows a possible inverse relationship between men's pay in annual service and fertility, particularly after the Black Death. There is no clear relationship with women's pay (figure 7), as confirmed by correlation coefficients (table 7) and regression analysis (table 8), even if we restrict the period of analysis to the years after 1350 and consider both forms of pay, annual and day rates. ${ }^{21}$

Figure 7. Welfare ratios from annual pay, men and women, and constructed fertility rate, $1270-1540$

\footnotetext{
${ }^{20}$ The dummy is given a value of 1 when death rates reach 100, 2 when they reach 200.

${ }^{21}$ Alternative specifications included the reciprocal of the welfare ratios and change between years in the welfare ratio and fertility.
} 


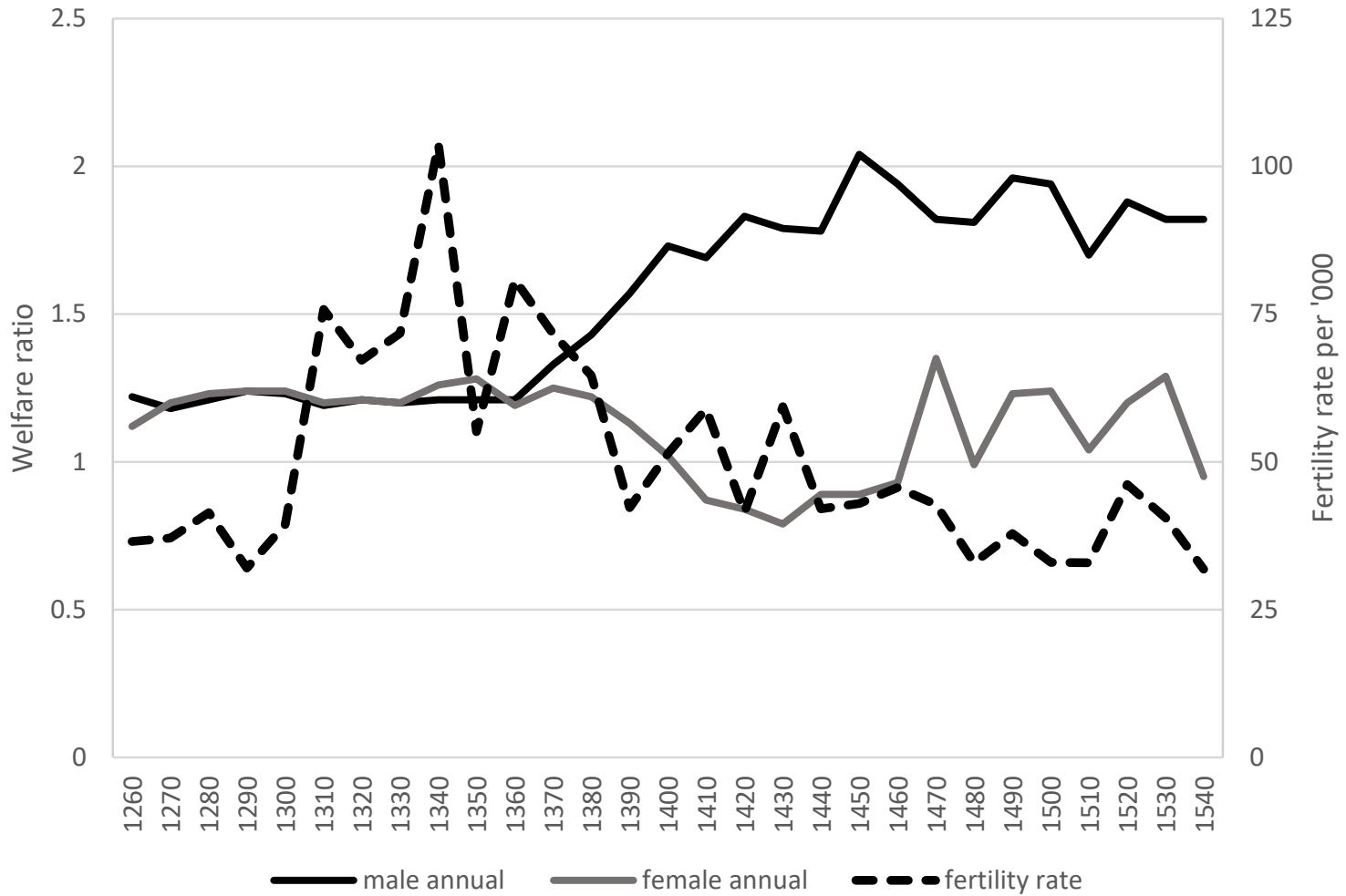

Table 7. Correlation coefficients and regression of determinants of medieval fertility rate (1350-1540 only)

\begin{tabular}{|l|l|l|}
\hline $\begin{array}{l}\text { Correlation } \\
\text { coefficients }\end{array}$ & $\begin{array}{l}\text { Pearson's correlation } \\
\text { coefficient }\end{array}$ & Significance \\
\hline Men annual & -0.739 & $0.00^{* * * *}$ \\
\hline Women annual & 0.137 & 0.56 \\
\hline Men day & -0.270 & 0.25 \\
\hline Women day & 0.156 & 0.51 \\
\hline Gender pay gap annual & -0.566 & $0.01^{* * *}$ \\
\hline Gender pay gap day & -0.465 & $0.04^{* * *}$ \\
\hline Sample size & 20 & \\
\hline
\end{tabular}

Significance at 10\%* $5 \% * *$, and $1 \% * * *$ 
Contrary to our previous findings, the medieval period exhibits a negative relationship between men's annual wages and our constructed fertility rate, improvements in men's economic position apparently reduced the likelihood of marriage and consequent births of the next generation. It may be that we observe a feature of the North-West European Marriage Pattern: as wages from annual work rose, couples deferred marriage and fertility, preferring instead to reap the benefits of high paid work in service. However, the tenuous relationship with the gender pay-gap from annual contracts speaks against this; as young women's relative economic position improved the gender pay gap fell but they opted for marriage and maternity, an observation more consistent with Bennett's (2019) argument that fewer people were able to afford to marry in these hard times. Indeed, these results are consistent with a strictly Malthusian interpretation of the economy: increased fertility and population drove men's remuneration back towards subsistence levels.

To disentangle these effects empirically we would need to find an instrument that is related to the wage but had no effect on fertility. Two available series might help, Clark's English prices and wages 1209-1914 which give annual data on wheat prices ${ }^{22}$ and Campbell's English crop yields 1211-1491.23 Wheat prices are not entirely exogenous, they affect the level of wages and the cost of living, but high population levels would also cause wheat prices to rise. Wheat yields, however, will affect wheat prices and hence wages but will primarily be dependent on climatic conditions so remain unrelated to the level of demand. We extract series for both these variables and take the average of the highest and lowest levels in each decade to use as an instrument for the wage in the fertility rate regressions. ${ }^{24}$ First stage regressions reveal that both wheat prices and wheat yields are significantly and negatively related to our welfare

\begin{tabular}{|c|c|c|}
\hline Welfare ratio & Average wheat price & Wheat yield \\
\hline Male day & $-0.620^{* * *}$ & $-0.616^{* * *}$ \\
\hline Male annual & $-0.654^{* * *}$ & $-0.598^{* * *}$ \\
\hline Female day & $-0.531^{* * *}$ & $-0.480^{* * *}$ \\
\hline Female annual & 0.272 & 0.254 \\
\hline Medieval fertility rate & $0.474^{* * *}$ & 0.149 \\
\hline
\end{tabular}


ratio remuneration variables, as predicted. ${ }^{25}$ But in the second stage regression, instrumenting the wage by wheat yield removes any significant effect of the wage on fertility (table 8). Using wheat price as an instrument results in male day and male annual welfare ratios having a significant negative effect on the fertility rate, but, as argued above, we consider this instrument is partially capturing an endogenous population element. We thus conclude that male wages were depressed by increasing fertility rates but that fertility, as constructed here, was unresponsive to male or female earnings in the medieval period. Instead, mortality was likely the main driver of population change with resultant effects on economic opportunity and rates of pay. This result is consistent with the observation that the moderate nuptiality and fertility regime exhibited by the NWEMP can only occur when mortality is also moderate (Wrigley 2014).

Table 8. Regression of male annual pay on constructed fertility rate, 1280-1540, using instrumental variables

(1)

\begin{tabular}{lc} 
VARIABLES & OLS \\
\hline Male annual pay & $-27.26 * * *$ \\
& $(9.616)$ \\
Constant & $92.80 * * *$
\end{tabular}

Observations 29 0.229

R-squared
(2)

IV wheat price

$-41.24 * * *$

$114.6 * * *$
(3)

IV wheat yield

Standard errors in parentheses

$* * * \mathrm{p}<0.01, * * \mathrm{p}<0.05, * \mathrm{p}<0.1$

\footnotetext{
${ }^{25}$ The first stage regressions both have a t statistic $>3.2$ on the coefficient for the instrument and $\mathrm{F}$ statistic $>10$ for the whole regression, showing that wheat price and wheat yield are both reasonable instruments to use in the second stage of the regression.
}

0.139 


\section{Section 5. Conclusion}

The evidence presented here suggests that for the medieval period, in the absence of clear effects of remuneration on marriage and fertility, the main impetus to population change may have been mortality. Declining population increased men's real remuneration and vice versa. But an underlying framework of institutions and mechanisms existed that also impacted on demography. Some, such as life-cycle servanthood, responded to economic stimuli in prosperous times and limited the erosion of any gains through population expansion, others, such as late age of marriage and life-time celibacy, were more closely aligned with parlous conditions. Medieval England was in a Malthusian world, although not one necessarily dominated by the positive check of dearth and want, but one nonetheless where nascent economic gains could be eroded by population expansion, albeit around an equilibrium level that ensured 'respectable' living. ${ }^{26}$ This world was characterised by aspects of the EMP but these were calibrated by poverty as much as responding to opportunity. It would take the move to early modern economic growth to put in place conditions that enabled female agency and women's desire to defer marriage when favourable economic opportunities presented to be operationalised on a broad front. We would suggest that only then was the European Marriage Pattern as a beneficent, environmentallycalibrated, and girl-empowering system fully in place. This conclusion hinges, however, on not overlooking, as Malthus did, the role played by women's and children's contributions.

\footnotetext{
${ }^{26}$ See Horrell, Humphries and Weisdorf (2020) for a measure of family welfare over this period. After the Black Death a typical family, through the work of all family members, was usually able to assure a 'respectable' standard of living.
} 


\section{References}

Allen, Robert C. (2010) 'The Great Divergence in European wages and prices from the Middle Ages to the First World War', Explorations in Economic History, 38, pp.411-47

Allen, Robert C. and Weisdorf, Jacob (2011) 'Was there an 'Industrious Revolution' before the Industrial Revolution? An Empirical Exercise for England, c. 1300-1830', Economic History Review, 64, pp. 715-29.

Armstrong, David M. (1994) 'Birth, marriage and death in Elizabethan Cumbria', Local Population Studies, 53, pp.715-29

Bailey, Mark (1996) "Demographic decline in late medieval England: some thoughts and recent research”, Economic History Review, 49, pp. 1-19.

Basu, Kaushik (1999) 'Child labor: cause, consequence and cure, with remarks on labor standards', Journal of Economic Literature, 37, pp.1083-119

Bennett, Judith M. (1987) Women in the medieval English countryside: gender and household in Brigstock before the plague, Oxford University Press

Bennett, Judith M. (2010) 'Compulsory service in late medieval England', Past and Present, 209, pp.7-51.

Bennett, Judith M. (2019) 'Wretched girls, wretched boys and the European Marriage Pattern in England (c.1250 - 1350)', Continuity and Change, 34, pp.315-47

Broadberry, Stephen, Bruce M.S. Campbell and Bas van Leeuwen (2010), 'English medieval population: reconciling time series and cross sectional evidence', Working paper, 27 July. Accessed online.

Broadberry, Stephen, Campbell, Bruce M.S., Klein Alexander, Overton, Mark and van Leeuwen, Bas (2015) British Economic Growth, CUP, Cambridge.

Cinnirella, Francesco, Marc Klemp, and Jacob Weisdorf (2017), 'Malthus in the Bedroom: Birth Spacing as Birth Control in Pre-Transition England', Demography 54, pp. 413-436.

Cinnirella, Francesco Marc Klemp, and Jacob Weisdorf (2019), 'Further Evidence of WithinMarriage Fertility Control in Pre-Transitional England', Demography, 56, pp.1557-72.

Clark, Greg, (2007) 'The Long March of History: Farm Wages, Population and Economic Growth, England, 1209-1869', Economic History Review, 6o, pp. 97-136.

De la Croix, David, Eric Schneider and Jacob Weisdorf (2019) 'Childlessness, celibacy and net fertility in pre-industrial England: the middle-class evolutionary advantage', Journal of Economic Growth, 24, pp.223-56 
Davenport, Romola (2018) 'The first stages of the mortality transition in England: a perspective from evolutionary biology', working paper, Cambridge University.

De Moor, Tine, and van Zanden, Jan Luiten (2010) 'Girl Power: The European Marriage Pattern and Labour Markets in the North Sea Region in the Late Medieval and Early Modern Period,' Economic History Review, 63, pp. 1-33.

Dennison, Tracy and Sheilagh Ogilvie (2014) 'Does the European Marriage Pattern explain economic growth?', Journal of Economic History, 74, pp.651-93

Ecclestone, Martin (1999) 'Mortality of rural landless men before the Black Death: the Glastonbury head tax lists', Local Population Studies, 63, pp.187-220

Edwards, Jeremy and Sheilagh Ogilvie (2018) 'Did the Black Death cause economic development by 'inventing' fertility restriction?', cesifo working paper 7016

Feinstein, Charles H. (1998) 'Pessimism perpetuated. Real wages and the standard of living in Britain during and after the Industrial Revolution', Journal of Economic History, 55, pp.62558.

Foreman-Peck, James (2016) 'Economic-Demographic Interactions in Long Run Growth', Handbook of Cliometrics, ed. Claude Diebolt and Michael Haupert, Springer Reference, Heidelberg, New York, Dortrecht, London.

Foreman-Peck, James and Peng Zhan (2018) 'Late marriage as a contributor to the industrial revolution in England', Economic History Review, 71, pp.1073-99

Goldberg, P. J. P. (1992) Women, work and life-cycle in a medieval economy. Women in York and Yorkshire c.1300-1520, Clarendon Press, Oxford.

Goldstone, J. A. (1986) 'The demographic revolution in England: a re-examination', Population Studies, 40, pp.5-33

Hallam, H. E. (1985) 'Age at first marriage and age at death in the Lincolnshire fenland, 12521478', Population Studies, 39, pp.55-69

Hajnal, John (1965) 'European Marriage Patterns in Perspective', in Population in History: Essays in Historical Demography, edited by D.V. Glass, and E.C. Eversley, Edward Arnold, London.

Hanawalt, Barbara A. (1993) Growing up in medieval London: the experience of childhood in history, Oxford University Press

Hatcher, John (1994) 'England in the aftermath of the Black Death', Past and Present, 144, pp.3-35 
Hatcher, John (1997) Plague, population and the English economy, 1348-1530, London Macmillan

Hatcher, John (2003) 'Understanding the population history of England, 1450-1750', Past and Present, 180, pp.83-130

Hatcher, John (2011), "Unreal wages: long run living standards and the "golden age" of the fifteenth century?' in Commercial activity, markets and entrepreneurs in the middle ages: essays in honour of Richard Britnell, edited by B, Dodds and C.D. Liddy, Boydell, Woodbridge.

Hoffman Saul. D. and Susan L. Averett (2010) Women and the economy. Family, Work and Pay, Addison-Wesley, New York

Horrell, Sara and Humphries, Jane (2019) ‘Children's work and wages in Britain, 1280-1860', Explorations in Economic History, , pp.

Horrell, Sara, Jane Humphries and Jacob Weisdorf (2019) 'Family living standards over the long run, England 1280-1850', Past and Present (forthcoming)

Humphries, Jane, and Weisdorf, Jacob (2015) ‘The Wages of Women in England, 1260-1850', Journal of Economic History, 75, pp. 405-445.

Humphries, Jane and Weisdorf, Jacob (2019) 'Unreal Wages? Real Income and Economic Growth in England, 1260-1850', Economic Journal, , pp. 2867-87

Janssens, Angelique A.P.O. ed. (2007) Gendering the Fertility Decline in the Western World, Lang, Oxford.

Karras, Ruth M. (2012) Sexuality in medieval Europe: Doing unto others, Routledge (2 ${ }^{\text {nd }}$ edition)

Kelly, Morgan and Cormac O'Grada (2012) 'The preventive check in medieval and preindustrial England', Journal of Economic History, 72, pp.1015-35

Klemp, Marcus and Jacob Weisdorf (2019) 'Fecundity, fertility and the formation of human capital', Economic Journal, 129. pp.925-60.

Kowaleski, Maryanne (1999) “Appendix: Demographic tables" in Judith M. Bennett and Amy M. Froide (eds) Single women in the European past 1250-180o, University of Philadelphia Press, pp.325-44

Kussmaul, Ann (1981) Service in husbandry in early modern England, Cambridge University Press

Malthus, Thomas Robert (1798) An essay on the principle of the population, vol. 1 
Malthus, Thomas Robert (1803) An essay on the principle of the population, vol. 2

Nightingale, Pamela (2005) 'Some new evidence of crises and trends of mortality in late medieval England', Past and Present, 187, pp.33-68

Phelps-Brown Ernest H. and Sheila V. Hopkins (1962) 'Seven centuries of the prices of consumables, compared with builder's wage rates', in E. H. Carus-Wilson (ed.), Essays in Economic History, 3 vols. (London) 2, p. 195.

Poos, Lawrence R. (1991) A rural society after the Black Death: Essex 1350-1525, Cambridge University Press

Ramey, Valerie A. (2016) 'Macroeconomic shocks and their propagation', in John B. Taylor and Harald Uhlig (eds) Handbook of macroeconomics, vol. 2A, Elsevier, ch. 3.

Razi, Zvi (1980) Life, marriage and death in a medieval parish: economy, society and demography in Halesowen 1270-140o, Cambridge University Press

Shapland, Fiona, Mary Lewis, and Rebecca Watts (2016) "The lives and deaths of young medieval women: the osteological evidence”, Journal of Medical Archaeology, 15, pp.272-89

Smith, Richard M. (1979) "Some reflections on the evidence of the origins of the 'European Marriage Pattern' in England", in Christopher C. Harris (ed) The sociology of the family: new directions for Britain, University of Keele, pp.74-112

Smith, Richard M. (1981) 'Fertility, economy and household formation in England over three centuries', Population and Development Review, 7, pp.595-622

Smith, Richard M. (1988) 'Human resources' in G. Astill and A. Grant (eds) The countryside of medieval England, Oxford, pp.188-212

Smith, Richard M. (1999) "Relative prices, froms of agrarian labour and female marriage patterns in England, 1350-180o", in Isabelle Devos and Liam Kennedy (eds) Marriage and rural economy: Western Europe since 140o, Brepols, Brussels, pp.19-48

Smith, Richard M. (2009) 'Putting Benedictine monks in context: mortality in England, 13501540', unpublished paper, University of Cambridge

Smith, Richard M. (2018) "Marriage and fertility in different household systems", in N. Hopwood, R. Flemming and L. Kassell (eds) Reproduction: from Antiquity to the present day, Cambridge University Press, pp.347-6o.

van Leeuwen, Marco H. D. and Ineke Maas (2011). HISCLASS: A Historical International Social Class Scheme. Leuven University Press. 
Voitländer, Nico and Voth, Hans-Joachim (2013) 'How the West 'Invented' Fertility Restrictions', American Economic Review, 103, pp. 2227-64.

Voth, Hans-Joachim (2000) Time and work in England, 1750-1830, Oxford, Clarendon Press

Weir, David (1984) 'Rather late than never: celibacy and age at marriage in English cohort fertility, 1541-1871', Journal of Family History, 9, pp.341-55

Whittle, Jane (ed.) (2017) Servants in rural Europe 1400-19oo, Boydell, Woodbridge Suffolk

Wrigley, E. A. (2004) 'British population during the 'long' eighteenth century, 1680-1840', in R. Floud and P. Johnson (eds) The Cambridge Economic history of Modern Britain, vol.1 Industrialisation, Cambridge University Press, pp.57-95

Wrigley, E.A. (2010) Energy and the English Industrial Revolution, Cambridge

Wrigley, E. A. (2014) “European marriage patterns and their implications: John Hajnal's essay and historical demography during the last half-century", in C. Briggs, P. Kitson, S. Thompson (eds) Population, welfare and economic change in Briatin, 1290-1834, Woodbridge, Boydell Press, pp.15-41

Wrigley, E.A. and Schofield, Roger (1981) The Population History of England 1541-1871: A Reconstruction, London, Edward Arnold

Wrigley, E.A., R.S. Davis, J.E. Oeppen, and R. S. Schofield (1997) English population history form family reconstitution, 1580-1837, Cambridge University Press.

Online resources:

Gregory Clark, "English prices and wages, 1209-1914", Wheat price in grammes of silver per litre (column FH), http://www.iisg.nl/hpw/data.php, accessed 16-01-202

Bruce M.S. Campbell (2007) "Three centuries of English crop yields 1211-1491", graph 1. Wheat yield per seed gross of tithe and net of seed. http://www.cropyields.ac.uk, accessed 1701-2020 
Appendix A.1. Average age of marriage from family reconstitution, by gender and social class

\begin{tabular}{|c|c|c|c|c|}
\hline \multirow{3}{*}{ Year } & \multicolumn{4}{|l|}{ Marriage age } \\
\hline & Men & Women & Men & Women \\
\hline & HISCLASS 9-12 & HISCLASS 9-12 & Unskilled $(11,12)$ & Unskilled $(11,12)$ \\
\hline 1540 & 25.89915 & & & \\
\hline 1550 & 26.93292 & & & \\
\hline 1560 & 23.65886 & 19.47224 & 23.47433 & \\
\hline 1570 & 19.27995 & 18.66537 & . & 17.05955 \\
\hline 1580 & 25.49133 & 24.45288 & 25.64618 & 22.807 \\
\hline 1590 & 26.45436 & 24.78832 & 27.06399 & 26.08178 \\
\hline 1600 & 26.97712 & 25.01597 & 27.3758 & 25.11255 \\
\hline 1610 & 27.90139 & 25.05161 & 27.99216 & 25.97972 \\
\hline 1620 & 28.15784 & 24.74103 & 29.4069 & 27.46981 \\
\hline 1630 & 28.58079 & 25.44705 & 28.56767 & 26.56756 \\
\hline 1640 & 29.62559 & 24.83579 & 28.12664 & 25.38871 \\
\hline 1650 & 27.54263 & 23.63704 & 26.30295 & 23.99197 \\
\hline 1660 & 27.78091 & 24.68546 & 24.64934 & 23.65014 \\
\hline 1670 & 28.01944 & 25.44711 & 27.72138 & 25.80892 \\
\hline 1680 & 26.57061 & 23.75378 & 27.02927 & 23.21749 \\
\hline 1690 & 27.18122 & 25.21029 & 27.17023 & 25.01926 \\
\hline 1700 & 27.7076 & 25.32798 & 26.66301 & 25.6879 \\
\hline 1710 & 26.94322 & 25.06425 & 26.22956 & 24.83388 \\
\hline 1720 & 27.30731 & 25.88355 & 28.24788 & 26.89288 \\
\hline 1730 & 27.66632 & 24.71529 & 27.57363 & 24.88712 \\
\hline 1740 & 27.4417 & 24.33024 & 29.00118 & 24.61414 \\
\hline 1750 & 27.43104 & 24.83053 & 28.17368 & 25.19285 \\
\hline 1760 & 27.05144 & 24.66583 & 27.33634 & 25.16461 \\
\hline 1770 & 26.84117 & 24.13883 & 27.1354 & 24.30474 \\
\hline 1780 & 27.49265 & 23.97098 & 27.67145 & 24.01859 \\
\hline 1790 & 26.03592 & 23.58341 & 26.44349 & 23.61194 \\
\hline 1800 & 25.60838 & 23.38544 & 25.61697 & 23.36112 \\
\hline 1810 & 25.13392 & 22.97282 & 25.09619 & 22.86041 \\
\hline 1820 & 25.58213 & 22.85263 & 25.78232 & 23.08223 \\
\hline 1830 & 25.58544 & 23.10477 & 25.39531 & 22.89047 \\
\hline 1840 & 26.26341 & 23.34881 & 26.4899 & 23.48604 \\
\hline
\end{tabular}


Appendix A.2

Table A.2 . Regression of children's remuneration with demographic variables, 15401860, Welfare ratio, 250 day working year

Model Summary
\begin{tabular}{|l|l|l|l|l|}
\hline Model & R & R Square & $\begin{array}{l}\text { Adjusted } \\
\text { Square }\end{array}$ & $\begin{array}{l}\text { Std. Error of } \\
\text { the Estimate }\end{array}$ \\
\hline 1 & $.652^{\mathrm{a}}$ & .425 & .419 & .55046 \\
\hline
\end{tabular}

ANOVAa
\begin{tabular}{|ll|c|c|c|c|c|}
\hline \multicolumn{2}{|c|}{} & Sum of & & & & \\
Model & & Squares & df & Mean Square & F & Sig. \\
\hline 1 & Regression & 719.220 & 36 & 19.978 & 65.933 & .000 $^{\mathrm{b}}$ \\
& Residual & 971.448 & 3206 & .303 & & \\
& Total & 1690.668 & 3242 & & & \\
\hline
\end{tabular}

a. Dependent Variable: standard of living per day in year assuming 250 days worked, measured in whole Allen baskets

\section{Coefficients ${ }^{a}$}

\begin{tabular}{|c|c|c|c|c|c|c|}
\hline & & Unstandar & Coefficients & $\begin{array}{c}\text { Standardized } \\
\text { Coefficients }\end{array}$ & & \\
\hline & & $\mathrm{B}$ & Std. Error & Beta & $\mathrm{t}$ & Sig. \\
\hline 1 & (Constant) & 1.105 & .191 & & 5.788 & .000 \\
\hline & approximate age in years & .082 & .004 & .273 & 18.237 & .000 \\
\hline & possibly an adult & .121 & .063 & .029 & 1.934 & .053 \\
\hline & construct & .720 & .049 & 253 & 14.626 & .000 \\
\hline & cottage & -.053 & .043 & -.034 & -1.219 & .223 \\
\hline & manufact & .108 & .046 & .046 & 2.346 & .019 \\
\hline & service & 199 & .044 & .080 & 4.579 & .000 \\
\hline & distrib & .542 & .064 & .124 & 8.421 & .000 \\
\hline & other occupation & 143 & .048 & .045 & 2.954 & .003 \\
\hline & haymaking & .384 & .063 & .086 & 6.048 & .000 \\
\hline & female dummy & -.423 & .175 & -.280 & -2.420 & .016 \\
\hline & female* decade time trend & -.003 & .007 & -.109 & -.486 & .627 \\
\hline & female * decade squared & .000 & .000 & .287 & 2.064 & .039 \\
\hline & boarddum & -.276 & .368 & -.140 & -.751 & 453 \\
\hline & lodgedum & .220 & .365 & .100 & .603 & .547 \\
\hline & clothdum & -.046 & .065 & -.012 & -.716 & .474 \\
\hline & board*decade trend & .013 & .008 & .307 & 1.610 & 107 \\
\hline & lodge ${ }^{*}$ decade trend & -.012 & .008 & -.250 & -1.553 & 121 \\
\hline & pay recorded as annual & -1.180 & .251 & -.630 & -4.701 & .000 \\
\hline & pay annual * decade trend & .020 & .006 & .491 & 3.392 & .001 \\
\hline & pay recorded as weekly & .144 & .034 & .099 & 4.237 & .000 \\
\hline & $\begin{array}{l}\text { pay is for task, day rate } \\
\text { assumed }\end{array}$ & -.285 & .081 & -.053 & -3.525 & .000 \\
\hline
\end{tabular}




\begin{tabular}{|c|c|c|c|c|c|}
\hline $\begin{array}{l}\text { identified as working } 30 \\
\text { days or more in source }\end{array}$ & -.148 & .035 & -.092 & -4.214 & .000 \\
\hline censuspoor & -.370 & .043 & -.179 & -8.639 & .000 \\
\hline makeworkscheme & -.404 & .053 & -.173 & -7.619 & .000 \\
\hline $\begin{array}{l}\text { data from spinning wages } \\
\text { source }\end{array}$ & -.199 & .050 & -.093 & -3.966 & .000 \\
\hline regionsw & -.451 & .154 & -.244 & -2.928 & .003 \\
\hline sw region * decade trend & .010 & .003 & .252 & 3.023 & .003 \\
\hline regionnw & -2.815 & .237 & -1.421 & -11.862 & .000 \\
\hline nw region* decade trend & .058 & .005 & 1.565 & 12.517 & .000 \\
\hline other region & -.060 & .039 & -.026 & -1.561 & .119 \\
\hline $\begin{array}{l}\text { child is observed in more } \\
\text { than one year }\end{array}$ & .133 & .029 & .074 & 4.624 & .000 \\
\hline $\begin{array}{l}\text { father and son paid } \\
\text { together }\end{array}$ & -.005 & .080 & -.001 & -.062 & .951 \\
\hline $\begin{array}{l}\text { works alongside father or } \\
\text { mother }\end{array}$ & .046 & .051 & .014 & .902 & .367 \\
\hline works with an adult & .149 & .041 & .060 & 3.633 & .000 \\
\hline decade number & -.014 & .002 & -.157 & -6.178 & .000 \\
\hline percent514inpop & -.018 & .008 & -.048 & -2.222 & .026 \\
\hline
\end{tabular}

a. Dependent Variable: standard of living per day in year assuming 250 days worked, measured in whole Allen baskets

Note: for full discussion of data and variables see Horrell and Humphries (2019) 
Appendix A.3. Alternative estimation methods: remuneration and demography 1540-1850.

Table A.3.1 Winsten-Prais standard errors to correct for serial correlation in error terms, $1540-1850$

\begin{tabular}{|c|c|c|c|c|}
\hline VARIABLES & $\begin{array}{c}(1) \\
\text { CMR }\end{array}$ & $\begin{array}{c}(2) \\
\text { CBR }\end{array}$ & $\begin{array}{c}(3) \\
\text { Pop 0-4 }\end{array}$ & $\begin{array}{c}\text { (4) } \\
\text { Pop 0-4 }\end{array}$ \\
\hline Male day & $\begin{array}{c}2.296 * * * \\
(0.506)\end{array}$ & $\begin{array}{c}3.215^{* *} \\
(1.352)\end{array}$ & & \\
\hline Women annual & $\begin{array}{c}-1.502 * * * \\
(0.477)\end{array}$ & $\begin{array}{l}-1.333 \\
(1.563)\end{array}$ & & $\begin{array}{l}-1.464 \\
(0.915)\end{array}$ \\
\hline Male annual & & & $\begin{array}{c}0.583 \\
(0.412)\end{array}$ & $\begin{array}{c}1.376 * * \\
(0.567)\end{array}$ \\
\hline Women day & & & $\begin{array}{c}-1.689 * * \\
(0.732)\end{array}$ & \\
\hline Constant & $\begin{array}{c}5.517 * * * \\
(1.279)\end{array}$ & $\begin{array}{c}28.23 * * * \\
(3.910)\end{array}$ & $\begin{array}{c}13.60 * * * \\
(1.355)\end{array}$ & $\begin{array}{c}12.10 * * * \\
(1.065)\end{array}$ \\
\hline Observations & 31 & 31 & 31 & 31 \\
\hline R-squared & 0.767 & 0.762 & 0.710 & 0.675 \\
\hline
\end{tabular}

Only regressions with significant results reported

Our previous findings are robust to corrections for serial correlation. 
Test for stationarity in the data

To check that the results are not driven by correlated trends between the data series.

Table A.3.2 Dickey-Fuller test for unit roots 1540-1850

\begin{tabular}{|c|c|c|c|c|c|c|}
\hline & \multicolumn{2}{|c|}{$\begin{array}{l}\text { Dickey Fuller } \\
\text { (yt a random walk } \\
\text { with drift) }\end{array}$} & \multicolumn{2}{|c|}{$\begin{array}{l}\text { Dickey Fuller } \\
\text { ( } \mathrm{y}_{\mathrm{t}} \text { a random walk with } \\
\text { drift around a trend) }\end{array}$} & \multicolumn{2}{|c|}{$\begin{array}{l}\text { Augmented Dickey } \\
\text { Fuller } \\
\text { (If } \mathrm{u}_{\mathrm{t}} \text { serially correlated) }\end{array}$} \\
\hline & & Stationary & & Stationary & & Stationary \\
\hline Men day & $\begin{array}{l}-2.641 \\
(0.085)\end{array}$ & & $\begin{array}{l}-2.505 \\
(0.33)\end{array}$ & $\sqrt{ }$ & $\begin{array}{l}-1.532 \\
(0.52)\end{array}$ & $\sqrt{ }$ \\
\hline $\begin{array}{l}\text { Men } \\
\text { annual }\end{array}$ & $\begin{array}{l}1.080 \\
(0.995)\end{array}$ & $\sqrt{ }$ & $\begin{array}{l}-1.518 \\
(0.82)\end{array}$ & $\sqrt{ }$ & $\begin{array}{l}1.452 \\
(0.997)\end{array}$ & $\sqrt{ }$ \\
\hline $\begin{array}{l}\text { Women } \\
\text { day }\end{array}$ & $\begin{array}{l}-2.895 \\
(0.046)\end{array}$ & & $\begin{array}{l}-2.949 \\
(0.15)\end{array}$ & $\sqrt{ }$ & $\begin{array}{l}-1.654 \\
(0.455)\end{array}$ & $\sqrt{ }$ \\
\hline $\begin{array}{l}\text { Women } \\
\text { annual }\end{array}$ & $\begin{array}{l}-0.684 \\
(0.85)\end{array}$ & $\sqrt{ }$ & $\begin{array}{l}-2.395 \\
(0.38)\end{array}$ & $\sqrt{ }$ & $\begin{array}{l}-0.102 \\
(0.95)\end{array}$ & $\sqrt{ }$ \\
\hline CMR & $\begin{array}{l}-4.958 \\
(0.000)\end{array}$ & & $\begin{array}{l}-4.115 \\
(0.006)\end{array}$ & & $\begin{array}{l}-3.008 \\
(0.034)\end{array}$ & \\
\hline CBR & $\begin{array}{l}-1.826 \\
(0.37)\end{array}$ & $\sqrt{ }$ & $\begin{array}{l}-2.840 \\
(0.18)\end{array}$ & $\sqrt{ }$ & $\begin{array}{l}-1.022 \\
(0.75)\end{array}$ & $\sqrt{ }$ \\
\hline Pop. 0-4 & $\begin{array}{l}-1.915 \\
(0.325)\end{array}$ & $\sqrt{ }$ & $\begin{array}{l}-2.293 \\
(0.44)\end{array}$ & $\sqrt{ }$ & $\begin{array}{l}-1.569 \\
(0.50)\end{array}$ & $\sqrt{ }$ \\
\hline
\end{tabular}

Test statistic reported. Compared with critical value, Mackinnon approximate p-value for $\mathrm{Z}(\mathrm{t})$ (level at which significant) in parentheses.

However defined, the test confirms that nearly all the series are stationary, the exception is the Crude Marriage Rate, which has a strong unit root in the series. There is also some doubt over men's day and women's day rates in the simplest specification, although this disappears if either a trend is included, even though the trend itself isn't significant, or the Augmented DF test is used. 
Indeed, there is doubt over the reliability of the test with 30 observations or less (we have 30) with the Dickey Fuller test being more likely to detect a unit root. Instead some have suggested that looking at the data itself is the most reliable guide in these cases, see figures below.

Figure A.3.1 CMR and men's and women's remuneration

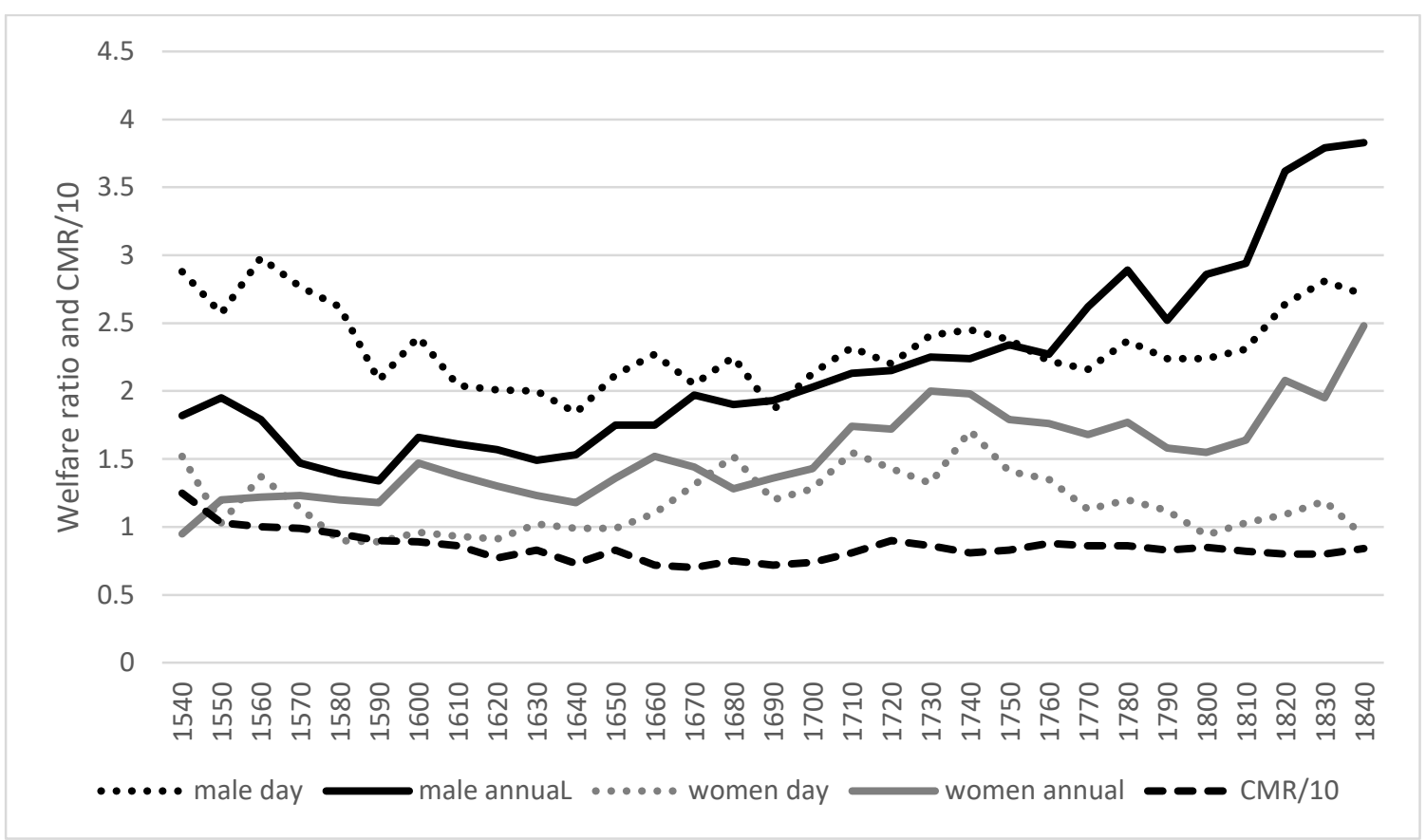

Figure A.3.2 CBR and men's and women's remuneration 1540-1850 


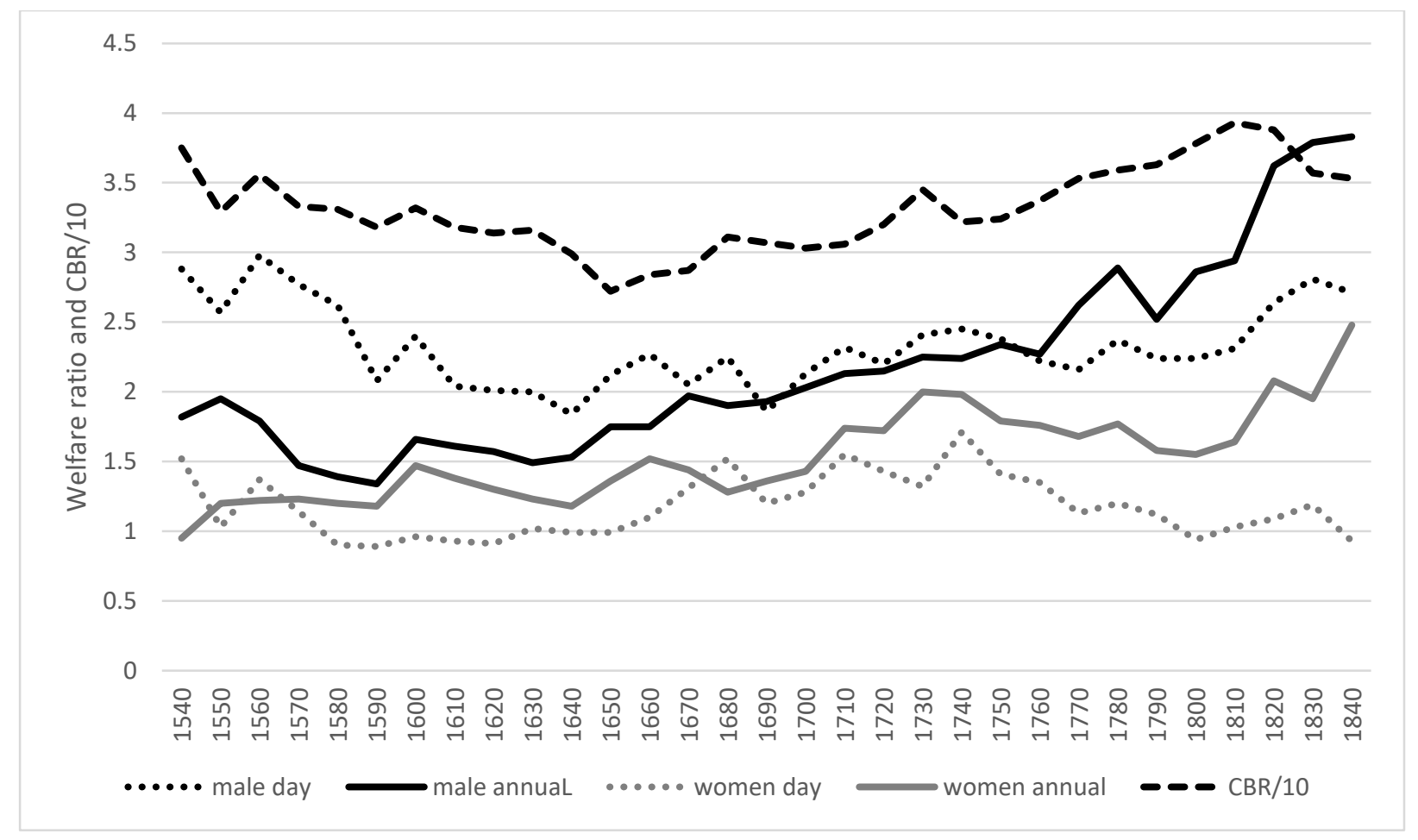

In general, we are satisfied that the series are stationary, with the exception of CMR.

Possible corrections for unit roots that transform the data to a stationary series are (a) to difference the variables (b) estimate the model in log levels, possibly with deterministic trends (Ramey 2016). Differenced variables performed weakly once robust standard errors were employed, with nearly all variables insignificant in the regression. This could result from only CMR being non-stationary, not the independent variables. The natural logarithm variant has greater traction.

Table A.3.3 Regression: determinants of CMR using logarithms of variables

\begin{tabular}{lccc}
\hline \multirow{2}{*}{ VARIABLES } & $(1)$ & $(2)$ & $(3)$ \\
& $\ln \mathrm{CMR}$ & $\ln \mathrm{CMR}$ & $\ln \mathrm{CMR}$ \\
\hline \multirow{4}{*}{ ln men annual } & $0.491^{* * *}$ & & $0.482^{* * *}$ \\
& $(0.143)$ & & $(0.126)$ \\
ln women annual & -0.0258 & $-0.262^{* * *}$ & \\
& $(0.147)$ & $(0.0699)$ & \\
time & $-0.0192^{* * *}$ & & $-0.0196^{* * *}$ \\
& $(0.00410)$ & & $(0.00444)$ \\
ln men day & & $0.689^{* * *}$ & \\
& & $(0.119)$ & \\
ln women day & & & 0.0362 \\
& & & $(0.0847)$
\end{tabular}




\begin{tabular}{lccc} 
Constant & $2.091 * * *$ & $1.662 * * *$ & $2.088 * * *$ \\
& $(0.0458)$ & $(0.0928)$ & $(0.0462)$ \\
& & & \\
Observations & 31 & 31 & 31 \\
R-squared & 0.470 & 0.614 & 0.472 \\
\hline
\end{tabular}

Robust standard errors in parentheses

$* * * \mathrm{p}<0.01, * * \mathrm{p}<0.05, * \mathrm{p}<0.1$

Note: Time trend variables were dropped if insignificant.

The results confirm our previous findings: the Crude Marriage Rate rose when men's wages rose and, in this specification, show the same responsiveness to men's annual remuneration as they do to men's day wages. CMR fell as women's remuneration in annual service rose, there was no effect from women's day wages. Our previous interpretation remains robust to an alternative empirical specification. 